\title{
Pesquisas arqueológicas paleoindígenas no Brasil ocidental
}

EURICO TH. MiLleR ${ }^{1}$

\section{Introdução}

O enfoque especial às pesquisas arqueológicas paleoindígenas, através do Programa Paleoindígena (PROPA), sob os auspícios da Smithsonian Institution (SI), iniciado em 1972, deve-se aos resultados preliminares obtidos em 1968, no oeste do Rio Grande do Sul (Miller 1969), quando do Programa Nacional de Pesquisas Arqueológicas (PRONAPA).

Além da SI, as pesquisas no Rio Grande do Sul envolveram, diretamente. ao Museu Arqueológico do Rio Grande do Sul (MARSUL) e à Fundação de Amparo à Pesquisa no Rio Grande do Sul (FAPERGS).

A continuidade dessas pesquisas, fora do Rio Grande do Sul, através: 1) do Programa Paleoindígena, e 2) do Programa Nacional de Pesquisas Arqueológicas na Bacia Amazônica (PRONAPABA), foi possível sob os patrocínios da SI, MARSUI, National Geographic Society (NGS) e Tinker Foundation, para o Mato Grosso.

Em Rondônia, as pesquisas arqueológicas com resultados paleoindígenas, devem-se ao PRONAPABA e ao Programa Arqueológico de Rondônia (PAR) da Secretaria de Estado de Cultura, Esportes e Turismo (SECET-RO).

Esses Programas tornaram-se possíveis graças ao Convénio entre o Conselho Nacional de Desenvolvimento Científico e Tecnológico (CNPq) e a Smithsonian Institution, com aprovação da Secretaria do Património Histórico e Artístico Nacional (SPHAN) e a colaboração do Instituto Nacional de Pesquisas da Amazônia (INPA); tendo como directores científicos Clifford Evans, Betty J.

1 Co-genitor (1964-66), Pesquisador e Diretor do MARSUL (1966-80); Pesquisador do PRONAPA (1965-70), PROPA (1972-77) e PRONAPABA (1976-); Diretor do PAR-SECETRO (1974).
Meggers (SI), Mário F. Simões (CNPq-Museu Goeldi) e Eurico Th. Miller (PAR-SECET-RO).

Os resultados preliminares foram apresentados sucintamente em oito comunicações (Miller 1976, 1978 Ms-a, 1978 Ms-c, 1978 Ms-d, 1978 Ms-e, 1983, 1985, 1986).

\section{Ambiente e geologia}

Rio Grande do Sul. Nas regiões fisiográficas da Campanha e Missões no oeste do Rio Grande do Sul, e dentre os municípios que estas comportam, foram pesquisados especialmente: Uruguayana e Quaraí à sudoeste entre os rios Uruguay e Quaraí, Alegrete e Itaquí no centro-oeste e, São Borja à noroeste (Figura 1).

Ao rio principal, o Uruguay (médio), seguem-se os rios Ibicuí ao centro da área. Quaraí ao sul, Icamaquã e Ijuí ao norte, arroio Touro Passo no centro-sul e, dezenas de córregos (arroios) menores. Somente o rio Uruguay tem suas nascentes sobre o Planalto Meridional (basalto-trapp), próximo ao litoral.

Clima é vegetação

$\mathrm{O}$ clima e do tipo $\mathrm{Cfa}_{2}$ (Köppen) subtropical com quatro estações distintas. A temperatura média anual é pouco abaixo de $20^{\circ} \mathrm{C}$, a média das máximas (janeiro) pouco superior a $25^{\circ} \mathrm{C}$ e a média das mínimas (julho) inferior a $15^{\circ} \mathrm{C}$. As máximas absolutas podem ultrapassar $40^{\circ} \mathrm{C}$ e as mínimas absolutas podem ser inferiores a $-4^{\circ} \mathrm{C}$. A média do mês mais quente ultrapassa $26^{\circ} \mathrm{C}$. A pluviometria normal anual está abaixo de $1400 \mathrm{~mm}$ e a mínima anual, pouco acima de $600 \mathrm{~mm}$, ocorre principalmente no autono (de março a maio). Os ventos predominantes são de SE e NE. A umidade relativa gira ao redor de $75 \%$ com uma insolação entre 2500 e 2600 he evaporação aproximada de $1600 \mathrm{~mm}$. As geadas, como até 30 dias/ano, podem ocorrer de abril a novembro. O clima se torna seco e quente com o Ciclone do Chaco; seco e frio com o Anticiclone do Pacífico (Moreno 1961). 


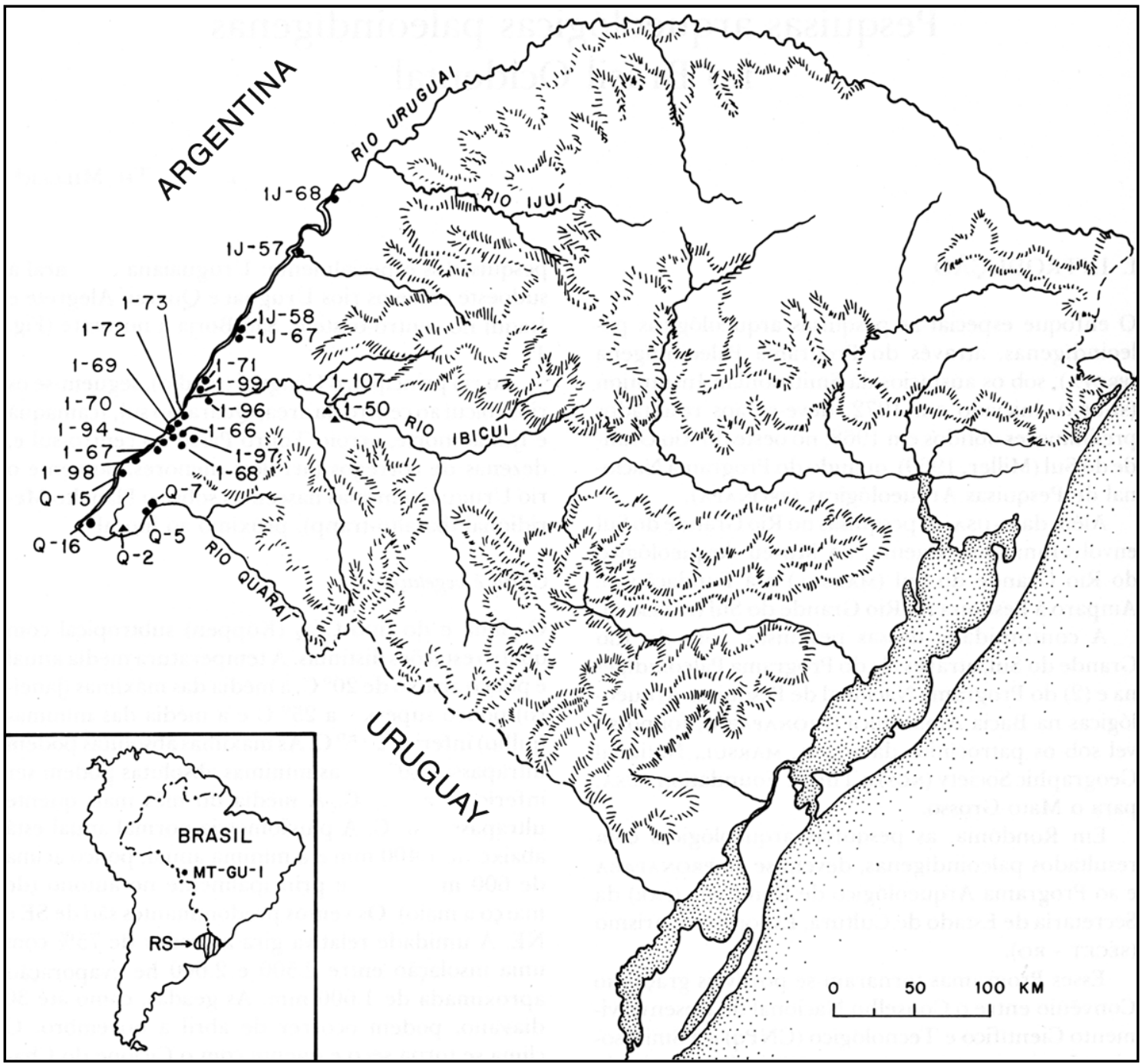

Figura 1. Localização dos sítios paleondígenas das fases Ibicuí $(\boldsymbol{\Delta})$ e Uruguay

A vegetação é composta basicamente de gramíneas (campo limpo), matas ciliares descontínuas ao longo dos rios e córregos e formações arbusto-arbóreas (capões) ao redor de brejos, no talvegue de vales e base de encostas.

\section{Geologia e geomorfologia}

Sobressaem as rochas basálticas da Serra Geral Grupo São Bento (Jurássico-Cretácio), o arenito Botucatu (Jurássico) e pseudodiques de metaquartzito (arenito silicificado) oriundo do pirometamorfismo entre a lava e arenito. No arroio Touro Passo ocorrem os sedimentitos da Formação Touro Passo (Bombim 1976), como provavelmente ocorrem nos pequenos rios e córregos, junto ao rio Uruguay na Campanha e parte de Missões. No rio Uruguay ao longo dos diques marginais percebe-se com muita nitidez o Estratotipo Miller-Varela (Correa 1980) composto de cinzas vulcânicas, silt e areias; esse Estratoguia está menos definido nos afluentes.

Como testemunho da dissecação das superfícies basaltica, metaquartzitica e arenítica, ocorrem elevações tabuliformes (mesa), quase sempre isoladas; superfícies suavemente onduladas (coxilhas), com altitudes raramente acima de $200 \mathrm{~m}$ (Cerro do Jarau $308 \mathrm{~m}$ ). As enchentes fluviais erodem ativamente os diques marginais e raramente inundam as planícies do rio Uruguay, ocorrendo o contrário nas planícies dos tributários, que permanecem depositários de sedimentos, quando a vazão é contida pelo rio 
Uruguay. As planícies dos tributários apresentam coloração cinza escuro a preto, textura argilosa muito plástica e pegajosa, com estrutura granular a blocos subangulares e firmes. Datações de $\mathrm{C}^{14}$ atribuem cerca de 6500 anos AP para o início dessa formação (a mesma datação ocorre na base de solos negros do Pantanal do Guaporé-Rondônia).

\section{Estratigrafia}

Em síntese, apesar de haver uma sequência sedimentar bastante similar, pela combinação litológica e modificações climáticas, podemos observar quatro variantes maiores na estratigrafia às margens dos rios e afluentes, refletindo influências geológicas ora locais ora distantes.

$1^{\text {a }}$ variante: Ao longo do rio Uruguay e abaixo da confluência com o rio Ibicuí;

$2^{a}$ variante: Ao longo do rio Uruguay e acima da confluência com o rio Ibicuí;

$3^{\mathrm{a}}$ variante: Ao longo do arroio Touro Passo e rio Quaraí;

$4^{\mathrm{a}}$ variante: Ao longo do rio Ibicuí.

Este sistema de variantes, subdivididas numa sequência de até nove horizontes estratigráficos (Miller 1976) e agrupadas em três unidades estratigráficas (Miller 1978 Ms-a), nos permite interrelacionar todas as ocorrências paleoindígenas, dentro de toda a área pesquisada, tomando como referência a base da unidade estratigráfica II (horizontes V e VI) ou horizonte $\mathrm{V}$, composto de cinzas vulcânicas, constituindo-se num estratoguia (Estratotipo Miller-Varela) (Correa 1980). Análises mais recentes sugerem uma datação ao redor de $10400 \pm 110$ AP $(\mathrm{N}-2521)$ para esse estratoguia. A unidade estratigráfica III (horizontes VII a IX) é a que contem as evidências paleoindígenas propriamente ditas (mais de 12000 AP) e as evidências "paleoindígenas remanescentes" (Ab'saber in Schmitz et al. 1978/79/80, com menos de 12000 AP (Tabla 1).

Portanto as evidências arqueológicas abaixo da unidade II pertencem ao Período Paleoindígena (Figura 2). Pelo menos nas porções dos baixos cursos dos afluentes do rio Uruguay, e neste, desde o rio Icamaquã até o rio Quaraí (Brasil, Argentina e Uruguay), este modelo com base no Estratotipo Miller-Varela é perfeitamente aplicável.
Considerações sobre a unidade estratigráfica II: à base do horizonte VI e topo do horizonte V. A unidade II apresenta sua porção inferior de cor branquicenta com até $1.6 \mathrm{~m}$ de espessura. Por sua consistência é a que mais resiste ao intemperismo e erosão fluvial, podendo assumir a forma de "marquise" sobre a unidade III e formar patamares em relação à unidade I no rio Uruguay e ocasionalmente no baixo curso dos afluentes. Ela tanto pode estar emersa como imersa ao nivel médio do rio Uruguay, visto que se desdobra de acordo com a paleotopografia. Essa discordância permite levantar o paleotraçado das margens do rio Uruguay, ora diverso em relação ao traçado Pleisto-Holocênico.

A pesar dos exames acurados, o horizonte VI de até $110 \mathrm{~cm}$ de espessura da unidade II não apresentou nenhuma evidência arqueológica e/ou paleontológica, a não ser pedotubulos paleofitológicos. Somente quando em mergulho e quase submersa ao n.m.r., a porção superior desta unidade apresenta evidências lítico-arqueológicas e outras (carvão). Estas particularidades parecem testemunhar um período de clima semi-árido, cerca de 9000 anos AP, quando o rio Uruguay teria se contraido ao talvegue (Miller 1974, Figura 1). Com o posterior aumento pluviométrico, os sítios paleoindígenas e do Arcaico Inferior foram quase totalmente destruidos pela erosão fluvial; esse modelo explicaria a ausência ou presença de evidências arqueológicas, de acordo com a maior ou menor altimetria da base da unidade II em relação ao n.m. do rio Uruguay. Com a idéia de um clima semi-árido também concorda a extinção e atulho de leitos de canais de drenagem (arroios) com restos vegetais carbonizados da unidade III, pela unidade II, e a reabertura dos canais de drenagem noutros lugares próximos, através da unidade I, atingindo as vezes o embasamento rochoso.

Mato Grosso e Rondônia. Os sítios paleoindígenas nesses Estados, conhecidos no presente, encontramse nos vales dos rios Guaporé, na encosta superior da Chapada dos Parecis (MT e RO) e nos sedimentos atualmente sempre imersos nas águas do alto rio Madeira (RO).

\section{Clima e vegetação}

Actualmente o clima é do tipo Am (Köppen) para toda a área de Rondônia e Aw no Mato Grosso. O tipo Am corresponde ao Tropical chuvoso e o mês mais frio com temperatura sempre acima de $18^{\circ} \mathrm{C}$; corresponde às florestas com chuvas do tipo monção. 


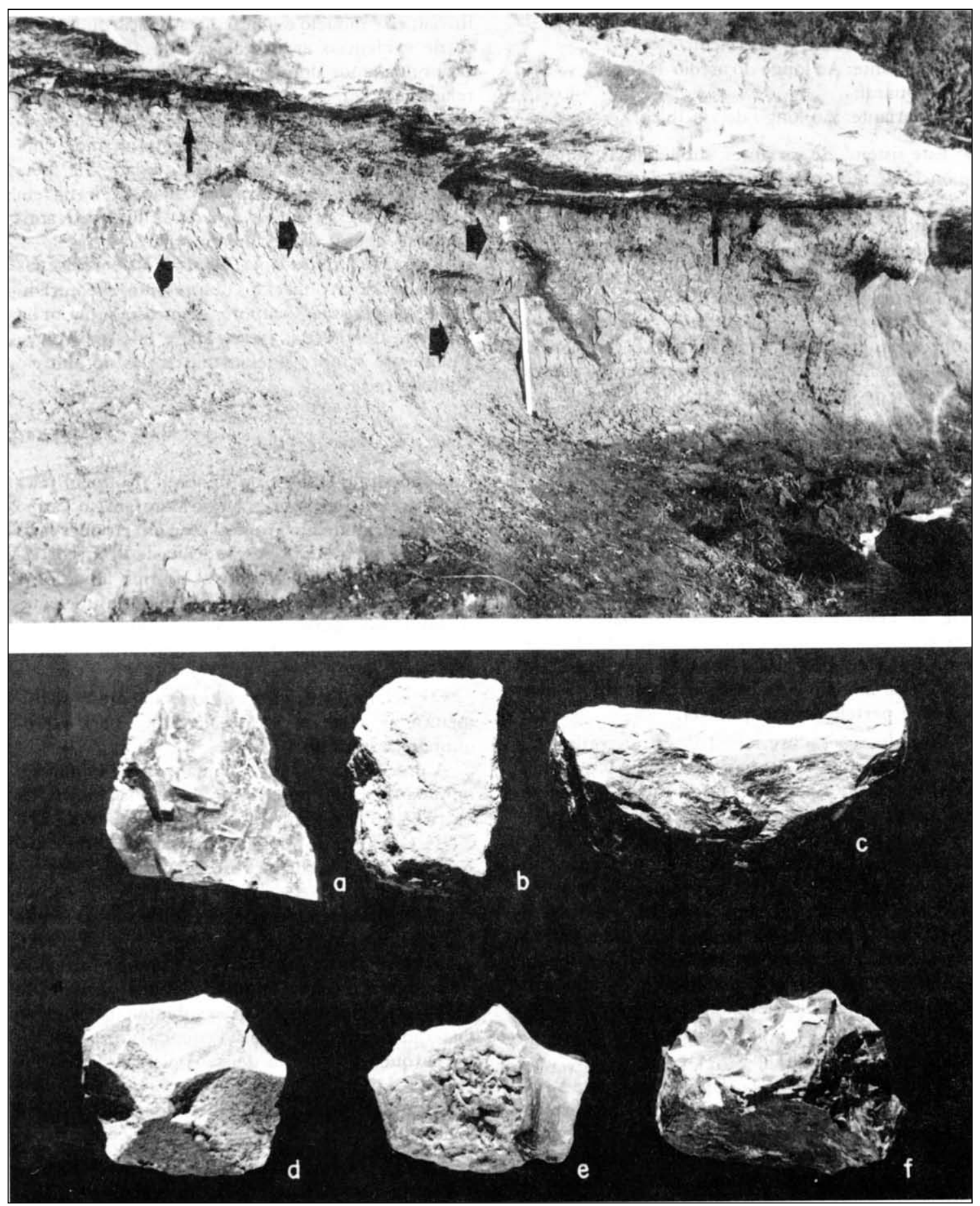

Figura 2. Vista parcial do sítio RS-IJ-67 da Fase Uruguay mostrando a camada de ocupação abaixo da unidade II. As setas indicam líticos "in loco": a, d) lascas; b-c, e-f) núcleos.

A estação seca é de pequena duração, mas suficientemente úmido para a existência de florestas. O Aw refere-se às savanas tropicais, com verão úmido e inverno seco.
O bioclima(Gaussen)é respectivamente Xeroquimênica Sub-termaxérica (seca curta), e Termoxeroquimênica (seca de quatro meses). 
A precipitação anual máxima é de $2250 \mathrm{~mm}$ e a mínima de $1500 \mathrm{~mm}$. A umidade relativa acha-se entre $85-80 \%$. A temperatura média anual é de $25 \mathrm{e}$ $24^{\circ} \mathrm{C}$. O regime de temperatura e umidade do solo é o Údico e o Ústico para o Planalto dos Parecis e regiões serranas.

A região do alto rio Madeira, fitoecologicamente compreende uma região de floresta tropical aberta, uma sub-região de superfície dissecada, de formação submontana e relevo ondulado. Pequenas áreas de tensão ecológica em formações submontanas e relevo dissecado; terraços aluviais. Pequenas áreas de savana parque, de floresta densa e planície aluvial. A encosta da Chapada dos Parecis é uma região de cobertura florestal estacional semidecidual tropical submontana, com tensão ecológica e contato com savana (Brasil, DNPM 1979).

\section{Geologia e geomorfologia}

Embasamento de rochas do Complexo Xingu. Formação Solimôes no alto rio Madeira com restos animais e vegetais, cobertura de argilitos, siltitos e arenitos; depósitos de planície de inundação. Áreas do grupo Uatumã com grupo Beneficiente: arenitos, siltitos eargilitos. Na Chapada dos Parecis ocorre cobertura de arenito da Fazenda Casa Branca (Carbonífero-Permiano) e Formação Parecis: arenitos finos (Cretáceo); sobre esta formação ocorrem testemunhos de capeamento basaltico. No alto rio Madeira predominan as formas de relevo de superfícies pediplanadas e transição para áreas dissecadas, interfluvios tabulares, colinas, pontões e áreas de acumulação inundáveis. No Chapadão observa-se encimando a cuesta arenitica, superfícies tabulares e, a montante, relevos escalonados (Brasil, DNPM 1979).

\section{Estratigrafia em abrigos}

As evidências Paleoindígenas, conhecidas na Chapada dos Parecis, ocorrem em abrigos-sobrocha, com $75 \times 25 \times 12.5 \mathrm{~m}$ e $39 \times 12 \times 8 \mathrm{~m}$. Por não constituirem sítios-habitação a contribuição à sedimentação e composição do solo foi praticamente mínima. Os sedimentos são coluvios arenosos, fracamente argilosos, resultante da decomposição e fragmentação da rocha arenitica que contém os abrigos, mais blocos de rocha vulcânica (basalto) que capeia partes da chapada, desabados em frente aos abrigos, onde o solo é areno-humoso. Nos 340 e $800 \mathrm{~cm}$ das escavações, os perfis apresentaram duas

\begin{tabular}{|lll|}
\hline Años AP & Sítio & N $^{\circ}$ Lab. \\
\hline Fase Uruguay & & \\
$8585 \pm 115$ & RS-IJ-67 & SI-2636 \\
$9035 \pm 100$ & RS-I-99 & SI-3755 \\
$9120 \pm 340$ & RS-I-70 & SI-2632 \\
$9230 \pm 145$ & RS-I-67 & SI-2625 \\
$9450+115$ & RS-I-72 & SI-2634 \\
$9595 \pm 175$ & RS-IJ-67 & SI-2637 \\
$9605 \pm 120$ & RS-I-97 & SI-3754 \\
$9620 \pm 110$ & RS-I-69 & SI-2631 \\
$9840 \pm 105$ & RS-I-67 & N-2519 \\
$9855 \pm 130$ & RS-IJ-67 & SI-3749 \\
$10180 \pm 110$ & RS-I-98 & SI-3752 \\
$10200 \pm 125$ & RS-I-69 & N-2522 \\
$10240 \pm 80$ & RS-I-69 & SI-3106 \\
$10400 \pm 110$ & RS-I-69 & N-2521 \\
$10800 \pm 150$ & RS-I-69 & N-2523 \\
$10810 \pm 275$ & RS-I-66 & SI-2622 \\
$10985 \pm 100$ & RS-I-69 & SI-2630 \\
$11555 \pm 230$ & RS-IJ-68 & SI-3750 \\
Fase Ibicuí & & SI-2351 \\
$12690 \pm 100$ & RS-Q-2 & SI-801 \\
$12770 \pm 220$ & RS-I-50 & SI-2350 \\
Sem associação cultural & RS-Q-2351 \\
$12690 \pm 100$ & RS-I-50B & SI-2348 \\
$17830 \pm 230$ & RS-I-50C & SI-2352 \\
$17850 \pm 190$ & RS-I-2 & \\
$19350 \pm 240$ & RS-Q-3 & \\
$29800 \pm 200$ & & \\
$33600 \pm 1500$ & RS-7 & \\
\hline
\end{tabular}

Tabla 1. Dataçôes dos sítios paleoindígenas das Fases Ubicuí e Uruguay.

unidades estratigráficas distintas (com datações $\mathrm{C}^{14}$ somente no sítio MT-GU-1, ver Tabla 2).

Unidade Superior: de zero a 230 e $430 \mathrm{~cm}$ (respectivamente RO-RO-07 e MT-GU-01) de espessura. Solo arenoso cinza claro, com pequenos blocos $(2-10 \mathrm{~cm})$ areníticos provenientes do teto dos abrigos. Essa unidade, em sua base de contato com a Unidade Inferior, apresenta um horizonte transicional gradual, com 30 e $90 \mathrm{~cm}$ de espessura, solo arenoso cinza esverdeado para cinza rosado escuro junto ao contato, com uma data $\mathrm{C}^{14}$ de $7970 \pm 75 \mathrm{AP}$ (SI-3475). Na porção superior ocorrem evidências culturais de grupos ceramistas e, na porção inferior, pre-cerámicos arcaicos. 
Unidade Inferior: Com mais de 70 e $370 \mathrm{~cm}$ (RORO-07 e MT-GU-01) de espessura (sem atingirem o início da ocupação humana). O contato dessa unidade com a Unidade Superior coincide com um horizonte de paleossolo pouco desenvolvido, cinza escuro, com $15 \%$ de pequenos blocos de rocha arenitica angular estratificada proveniente dos tetos dos abrigos, que aumentam drasticamente de tamanho (até $120 \times 150 \times 300 \mathrm{~cm}$ ) com a profundidade. $\mathrm{O}$ paleossolo apresenta uma espessura de 42 e $86 \mathrm{~cm}$; na porção inferior entre 480-500 $\mathrm{cm}$ apresenta as datações $\mathrm{C}^{14}$ de $8930 \pm 100$ anos AP (SI-3736) e 10600 \pm 130 anos AP (N-3223). Do paleossolo para baixo com coloração transicional de cinza escuro para cinza, entre 540 e $550 \mathrm{~cm}$, ocorrem duas datas $\mathrm{C}^{14}$ de $11800 \pm 110$ anos AP $(\mathrm{N}-3226)$ e $12300 \pm 95$ anos AP (SI-3477) datam possivelmente a transição Pleistoceno-Holoceno. Aos $530-540 \mathrm{~cm}$ e $560-580 \mathrm{~cm}$, duas datas de $\mathrm{C}^{14} \mathrm{com}$ $14700 \pm 195$ anos AP (N-2359) e 14470 \pm 450 anos AP (SI-3738) datam a transição de solo cinza para cinza claro com presença de pequenos e grandes blocos de arenito e rocha vulcânica (basalto) em frente ao abrigo (Figura 19). As datações abaixo de $580 \mathrm{~cm}$ são provenientes de amostras de carvão muito pequenas e mais recentes. Existem datações de dentro, de fora, e justapostas à linha de projeção de entrada do abrigo. Nessas três posições observam-se vertical e horizontalmente, discordâncias, que não invalidam a sequência cronológica, visto as datações selecionadas serem coerentes estratigraficamente (Tabla 2). Porém, necessário se faz que outras sequências, análogas cronológica e estratigraficamente, sejam encontradas para verificar a credibilidade destas datações.

\section{Estratigrafia no rio Madeira}

As evidências paleoindígenas do Complexo Periquitos ocorrem, até o presente, no leito do alto rio Madeira junto à Cachoeira dos Periquitos. As amostragens de sedimentos em dezenas de sondagens à $\mathrm{O}$ e $\mathrm{E}$, transversal à margem direita do rio acima e abaixo das cachoeiras, elaboradas pela Companhia de Pesquisa de Recursos Minerais (CPRM), forneceram colunas estratigráficas que, a grosso modo, apresentam un conjunto de três unidades litológicas da superfície do solo e espelho de água até o leito de rocha, desde a planície adjacente à margem até próximo ao talvegue.

Margem do rio: Sondagem em setembro/84, no auge da estiagem, em várias cachoeiras; Cachoeira dos Periquitos, sítio RO-GM-12, linha 271.375 (km 271.375 da EFMM, km O em Porto Velho) a $50,75,100$ e $125 \mathrm{~m} \mathrm{E}$ da margem direita.

Unidade Superior, com espessuras de 2.5 a $8 \mathrm{~m}$, constituída essencialmente por argila avermelhada e silte, apresenta coloração variegada de vermelho para esbranquiçada e cinza.

Unidade Mediana, com predominância de argila arenosa fina e silte com algumas porções laterizadas, coloração variegada de cinza claro a avermelhada, com espessuras de 4 a $9 \mathrm{~m}$. Ocorrem restos vegetais conservados em vários horizontes.

Unidade Basal, representada normalmente pelas frações grosseiras correspondendo a areia grossa argilosa e cascalho de seixos de quartzo, silte argiloso cor cinza com horizontes finos de laterita, grãos de quartzo e argila cor cinza a amerelado, com seixos de quartzo sobre o leito rochoso. Em vários horizontes ocorrem restos vegetais preservados. A espessura desta unidade varia entre 6.60 e $8.20 \mathrm{~m}$.

Leito do rio: Local Serraria a montante da Cachoeira dos Periquitos. Sondagens sobre a linha 280 (km 280 da EFMM) a 50, 150, 250 e $350 \mathrm{~m}$ da margem direita.

Unidade Superior, com espessuras de 6 até $8.50 \mathrm{~m}$, composta essencialmente por areia fina a média micácea, cinza escuro a amarelada e pontuações escuras com tonalidade marron, e grãos de quartzo anguloso. Ocasionalmente ocorrem restos arqueológicos cerâmicos e ossos humanos não mineralizados, bem como da biota, não mineralizados.

Unidade Mediana, predominância da fração arenosa fina, com mica, cinza a marrom. Possui as vezes contribuições argilosas de coloração variegada de cinza a marrom claro. Ocorrem finas camadas de cascalho com seixos de quartzo, silex, arenito e restos de madeira preservada. Ocasionalmente ocorre material grosseiro com seixos de quartzo e grânulos de silex e lateritas. A espessura da unidade varia de 2.5 a $7 \mathrm{~m}$.

Unidade Basal, representada normalmente pelas frações grosseiras correspondendo aos depósitos residuais de fundo é considerada de grande interesse na prospecção paleoindígena e da paleobiota, devido sua posição diretamente sobre o lito de rocha e cronologia transicional pleisto/holocênica. A espessura varia entre 0.95 (margem) e 4.65 
PESQUISAS ARQUEOLOGICAS PALEOINDIGENAS NO BRASIL OCIDENTAL

\begin{tabular}{|c|c|c|c|}
\hline \multirow{2}{*}{$\begin{array}{l}\text { Profundidad } \\
\text { (m) }\end{array}$} & \multicolumn{3}{|c|}{ Cuadrículas } \\
\hline & M-11/12 & $\mathrm{N}-11 / 12$ & $0-11 / 12$ \\
\hline \multirow{2}{*}{$2.10-2.20$} & $\begin{array}{l}315 \pm 70 \\
\mathrm{~N}-2357\end{array}$ & & \\
\hline & $\begin{array}{l}115+55 \\
\text { SI-3105 }\end{array}$ & & \\
\hline \multirow{2}{*}{$3.50-3.60$} & & $\begin{array}{l}5760 \pm 60 \\
\text { SI-3473 }\end{array}$ & $\begin{array}{c}9410 \pm 120 \\
\text { N-3227 }\end{array}$ \\
\hline & & $\begin{array}{c}6460 \pm 100 \\
\mathrm{~N}-3222\end{array}$ & $\begin{array}{l}9245 \pm 120 \\
\text { SI-3739 }\end{array}$ \\
\hline \multirow{2}{*}{$3.65-3.75$} & & $\begin{array}{l}6130 \pm 65 \\
\text { SI-3104 }\end{array}$ & \\
\hline & & $\begin{array}{c}7810 \pm 110 \\
\mathrm{~N}-2358\end{array}$ & \\
\hline $3.70-3.80$ & & & $\begin{array}{c}11600 \pm 115 \\
\mathrm{~N}-3055\end{array}$ \\
\hline $3.80-3.90$ & & $\begin{array}{c}7190 \pm 70 \\
\text { SI-3474 }\end{array}$ & \\
\hline $4.00-4.10$ & & $\begin{array}{l}7970 \pm 75 \\
\text { SI-3475 }\end{array}$ & \\
\hline $4.60-4.80$ & $\begin{array}{c}5900 \pm 105 \\
\mathrm{~N}-3056\end{array}$ & & \\
\hline \multirow{2}{*}{$4.80-5.00$} & & $\begin{array}{l}8930 \pm 100 * \\
\text { SI-3736 }\end{array}$ & \\
\hline & & $\begin{array}{c}10600 \pm 130 * \\
\mathrm{~N}-3223\end{array}$ & \\
\hline \multirow{2}{*}{$5.00-5.20$} & $\begin{array}{l}6730 \pm 85 \\
\text { N-3057 }\end{array}$ & $\begin{array}{l}7530 \pm 105^{*} \\
\mathrm{~N}-3224\end{array}$ & \\
\hline & & $\begin{array}{c}10405 \pm 100^{*} \\
\text { SI- } 3476\end{array}$ & \\
\hline \multirow{2}{*}{$5.20-5.40$} & & $\begin{array}{l}9775 \pm 70^{*} \\
\text { SI-3737 }\end{array}$ & \\
\hline & & $\begin{array}{l}11300 \pm 140^{*} \\
\mathrm{~N}-3225\end{array}$ & \\
\hline $5.30-5.40$ & & & $\begin{array}{c}14700 \pm 195 \\
\mathrm{~N}-2359\end{array}$ \\
\hline \multirow{2}{*}{$5.40-5.50$} & & $\begin{array}{c}11800 \pm 110^{*} \\
\mathrm{~N}-3226\end{array}$ & \\
\hline & & $\begin{array}{c}12300 \pm 95 * \\
\text { SI-3477 }\end{array}$ & \\
\hline \multirow{2}{*}{$5.40-5.60$} & $\begin{array}{c}7630 \pm 95^{*} \\
\text { N-3058 }\end{array}$ & & \\
\hline & $\begin{array}{c}7695 \pm 65^{*} \\
\text { SI- } 3740\end{array}$ & & \\
\hline $5.50-5.60$ & & $\begin{array}{l}5730 \pm 60 \\
\text { SI-3478 }\end{array}$ & $\begin{array}{c}7950 \pm 115 \\
\mathrm{~N}-3059\end{array}$ \\
\hline \multirow{2}{*}{$5.60-5.80$} & $\begin{array}{c}6900 \pm 65^{*} \\
\text { SI- } 3741\end{array}$ & & $\begin{array}{c}14470 \pm 450 \\
\text { SI- } 3738\end{array}$ \\
\hline & $\begin{array}{c}7220 \pm 85^{*} \\
\text { N-3060 }\end{array}$ & & \\
\hline $5.80-6.00$ & $\begin{array}{l}7130 \pm 85 \\
\text { N-3061 }\end{array}$ & $\begin{array}{r}9370 \pm 70 \\
\text { SI-3479 }\end{array}$ & \\
\hline $6.00-6.20$ & $\begin{array}{l}6470 \pm 110 \\
\mathrm{~N}-3062\end{array}$ & & \\
\hline $6.30-6.40$ & & $\begin{array}{l}7875 \pm 85 \\
\text { SI-3481 } \\
\end{array}$ & \\
\hline $6.50-6.60$ & & $\begin{array}{c}9115 \pm 160 \\
\text { SI-3482 } \\
\end{array}$ & \\
\hline \multirow[t]{2}{*}{$\leftarrow$ Interior } & \multicolumn{2}{|c|}{$\begin{array}{c}\text { Projeção do teto hoje } \\
\downarrow \downarrow\end{array}$} & Exterior $\rightarrow$ \\
\hline & Linha de $g$ & aproximada. & \\
\hline
\end{tabular}

Tabla 2. Dataçôes do sítio MT-GU-1, com procedência vertical e horizontal. * indica datações obtidas duma única amostra dividida e datada em dois laboratórios. 
(aos $350 \mathrm{~m}$ ) m e constitui-se de areia com granulometria média a grosseira em tons variegados de cinza com seixos de quartzo e silex normalmente subarredon-dados até $4 \mathrm{~cm}$ e fragmentos de composição laterítica. São comuns horizontes ou finas camadas de natureza conglomerática com sedimentos elásticos, cascalho de seixos e fragmentos de quartzo, granito, gnaisse, silex, anfibolito, arenito, etc., intensamente cimentados por silicificação; nesses horizontes são encontrados ossos fósseis de megafauna extinta e humanos, bem como alguns prováveis implementos líticos, lascas, percutores ou seixos com evidências concentradas em uma das estremidades.

Entre as Unidades Basais da margem e do leito do rio, ocorre alguma similaridade sedimentar e litológica; as diferenças litológicas aparecem e se acentuam a medida que se atinge a Unidade Superior. Essa similaridade entre as Unidades Basais pode representar a preservação de horizontes (ou porções destes) da transição Pleistoceno/Holoceno.

\section{Metodologia de campo}

Rio Grande do Sul. As pesquisas de campo de 1967 a 1968 permitiram relacionar os sítios paleoindígenas a características estratigráfico-geomorfológicas envolvendo aspectos como:

1) Estrato-guia composto de cinzas vulcânicas, sobre os sítios (Estratotipo Miller-Varela) (Correa 1980: 10, 11).

\section{2) Paleocanal de drenagem.}

3) Paleobacias de drenagem, assoreadas, e reativadas no Holoceno até o presente.

4) Diques marginais desnudados.

Com base nas características dos itens 3 e 4 determináveis em fotos aéreas e folhas cartográficas 1: 100.000 da Diretoria do Serviço Geográfico - DSG/ $1^{\circ} \mathrm{DL}$, foram demarcadas todas as áreas com possível ocorrência de sítios arqueológicos Paleoindígenas, junto ao rio Uruguay, afluentes maiores e menores, nas regiões fisiográficas de Missões e Campanha, no oeste do Rio Grande do Sul, entre os rios Quaraí ao sul da Campanha e Ijuí ao norte, em Missões. Referências bibliográficas e informações de ocorrência de fósseis da biota pleistocênica também foram cartografados.
Nas etapas de campo de 1972 a 1977 e esporadicamente até a atualidade, sempre na estiagem no verão (de dezembro a fevereiro) e as vezes no outono até os primeiros sinais do frio invernal (em maio/junho) foram reambuladas in loco algumas áreas selecionadas, determinando a presença do Estrato-guia e de paleocanais, junto as bacias de drenagem.

No rio Uruguay, o Estrato-guia se destaca dos demais estratos por sua resistência a erosão, formando por vezes como que uma marquise, que protege os sítios das chuvas, mas não da erosão fluvial (Figura 3). Nos afluentes o Estrato-guia não se destaca com tanta nitidez, apresentando por vezes uma transição gradual.

Os sítios foram prospectados através de cortesexperimentais e cortes estratigráficos, a partir do Estrato-guia (inclusive) mesmo aqueles encobertos por dique marginal íngreme, resultando um pequeno "abrigo" paralelepipediforme.

Precedendo os cortes, foram coletadas todas as evidências culturais e eventualmente ósseas fósseis, que jaziam sobre o solo, após as erosões fluviais anuais (Figura 4). Algumas coleções, sempre não selecionadas, além de artefatos da Fase Uruguay paleoindígena, apresentaram desde líticos do Complexo Itaquí Arcaico, até evidências lito-cerâmicas das fases Icamaquã ou Ibirapuitã. Estas coleções obviamente não foram consideradas no contexto da Fase Uruguay, mas, tão somente as coleções escavadas, in loco, nos estratos intáctos.

Os cortes foram efetuados em camadas de $10 \mathrm{em}$ $10 \mathrm{~cm}$ seguindo o gradiente das superfícies estratigráficas, nos estratos com mais de $10 \mathrm{~cm}$ de espessura; nas de menor, a espessura se restringia à respectiva potência. Estratos lodo-argilosos foram separados dos arenosos, composição presente na porção inferior do conjunto de estratos paleoindígenas, e sub divididos quando com mais de $10 \mathrm{~cm}$ de potência, seguindo as "varvas" de deposição fluvial. As camadas foram decapadas preferencialmente com instrumental de madeira, osso e plástico, em movimentos paralelos à estratigraíia e sub paralelos quando necessários; assim, as evidências líticas raramente eram tocadas prejudicialmente visto à posição estratigráfica paralela de ambos: artefato e instrumental de escavação. Quando necessário os fósseis foram desidratados com álcool e impregnados com cola translúcida incolor e solúvel. 


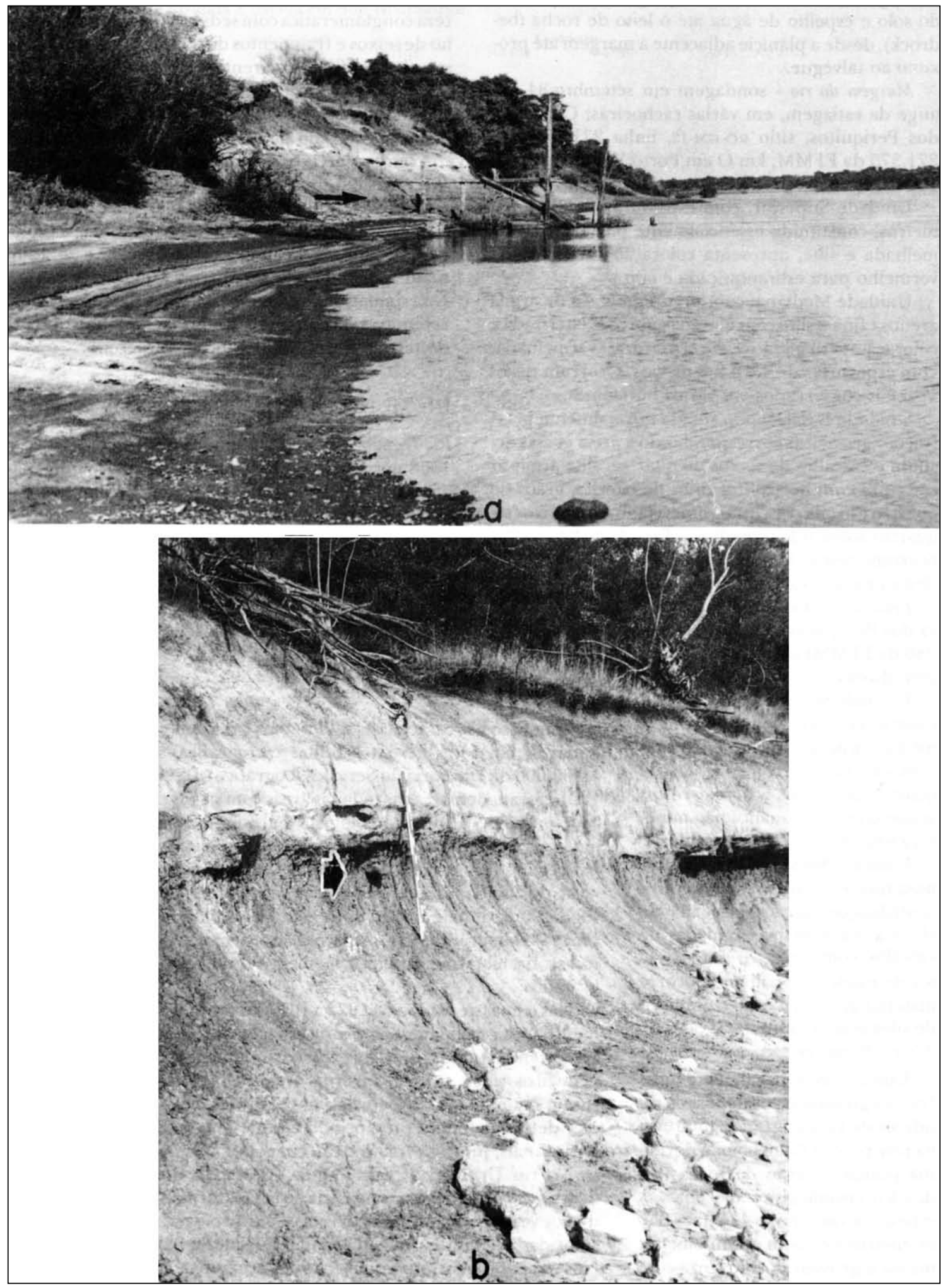

Figura 3. Sítios no rio Uruguay subjacentes à camada clara e estéril. a) RS-I-70: a seta indica ao nível mais profundo dos líticos; b) RS-I-72: a seta indica os líticos e o carvão datado ( $\mathrm{Si}=2634)$. 
Os sedimentos invariavelmente passaram por peneiras em série, de 2.4 e $6 \mathrm{~mm}$. Quando argilosos era necessário uma secagem prévia ao sol e após, sua lavagem. Devido às concreções de calcário (resultante de paleocondições de semi-aridez e subumidade) de mistura em sítios de afluentes do rio Uruguay, foi necessário o uso de luvas de couro. A aspersão hídrica foi realizada à motor com múltiplos esguichos.
As técnicas de escavação, estratigrafia e evidências culturais, antes de recolhidas foram ortogonalmente fotografadas, cartografadas e ocasionalmente filmadas em $8 \mathrm{~mm}$, in situ.

As paredes dos cortes quando desidratadas, esfarelavam e desabavam facilmente; para minimizar, foram utilizadas coberturas evitando as chuvas ocasionais

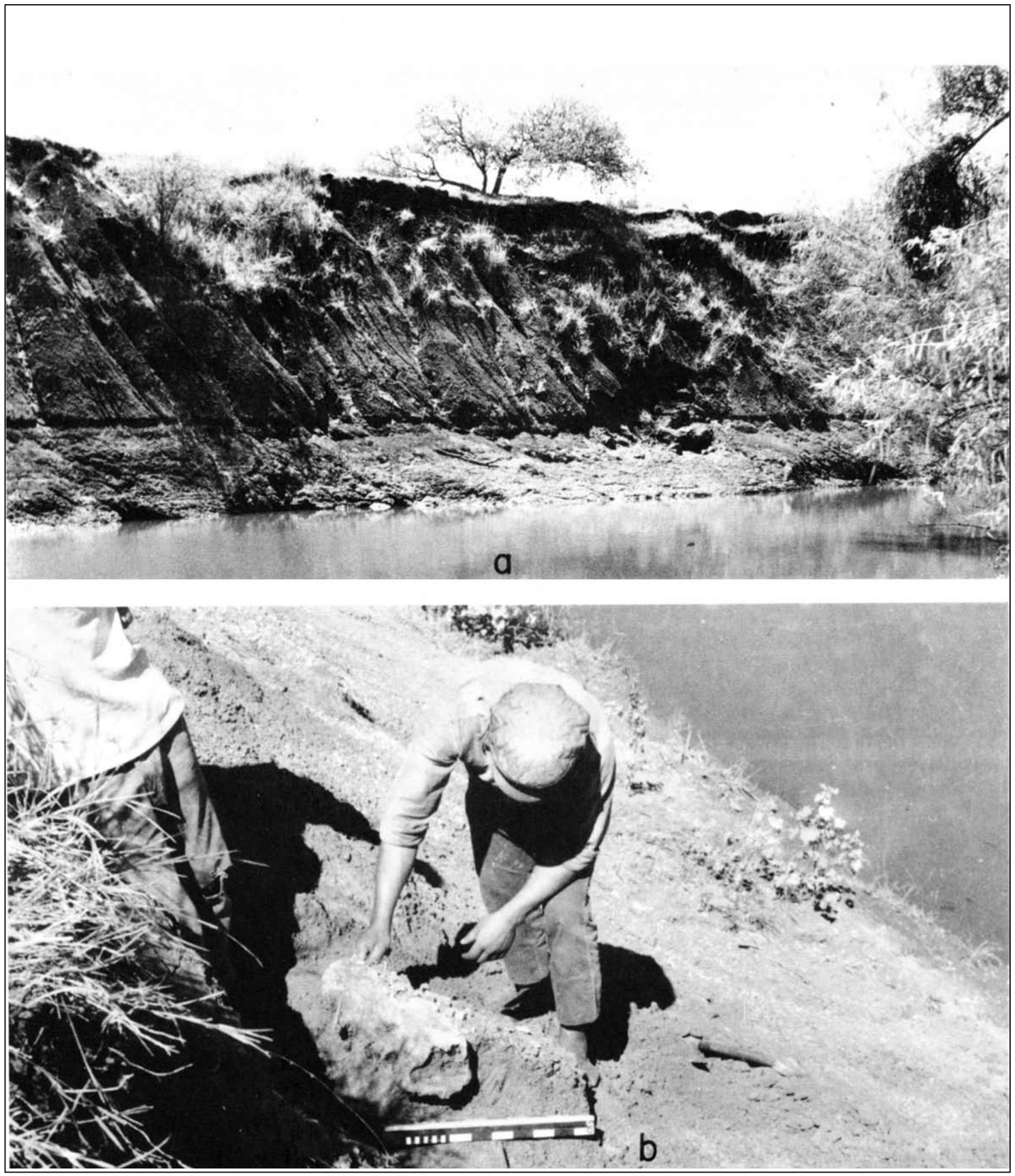

Figura 4. Sítio RS-I-50 da Fase Ibicuí com o crâneo de Glossoterium robustus “in loco”. 
e o ressecamento, e madeirame para escoramento dos sedimentos (Figuras 5 y 6 ).

O resultado arqueológico de cada camada levou um número e/ou vários conjuntos numéricos, e foi embalado separadamente. Foram extraídas várias amostras de carvão vegetal para dataçao radiométrica $\mathrm{C}^{14}$ sempre relacionadas a conjuntos culturais, paleocanais, Estrato-guia, pedo-tubulos, biota fóssil, transições sedimentares climáticas, e outros. Por sua consistência, foram extraídas várias placas irregulares como amostra, do estrato-guia, impregnadas de pedo-tubulos, folhas, carvão e evidências líticas, junto à superfície de contato com a porção superior dos sítios paleoindígenas da Fase Uruguay. Todos os dados posíveis foram anotados em fichas.

Contamos com a participação de dois especialistas: Miguel Bombim (1972) que publicou individualmente alguns de nossos resultados e ilustrações (Bombim 1976) como Pesquisador do MCPU CRGS; Juan Varela (1979) Professor de Pesquisa e Chefe do Lab. Sedimentología, Dep. Geologia da Univ. de Chile, Santiago. Os trabalhos de escavações chegaram a reunir 18 participantes entre especialistas e braçais.

Mato Grosso e Rondônia. Basicamente, os procedimentos metodológicos para o Mato Grosso e Rondônia, em sítios a céu aberto e abrigos-sobrocha foram os mesmos para o Rio Grande do Sul (Figuras 7 y 8). Junto ao rio Madeira contamos com perfurações estratigráficas de mineradoras e estudos próprios. Cartas batimétricas estão sendo elaboradas pela Marinha e serão de importância para as hipóteses levantadas.

Tanto em abrigos-sob-rocha como em sítios a céu aberto, no Chapadão dos Parecis e encosta superior

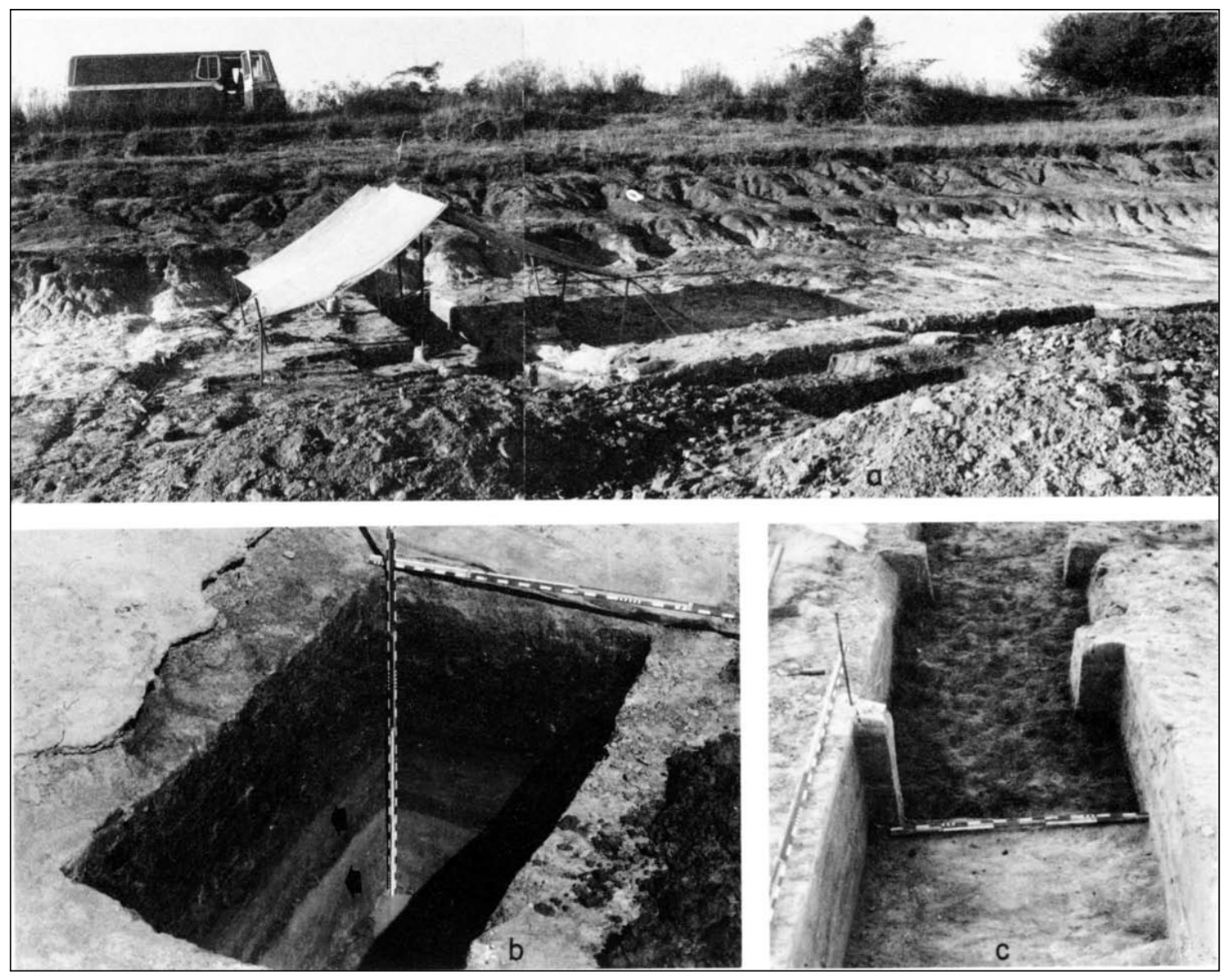

Figura 5. Metodología das escavações: a) RS-I-69, início das escavações; b) Estratigrafia de camadas intermitentes argilosas e arenosas. A seta superior assinala SI-2631; as inferiores, níveis arqueológicas com datações; c) Detalhe da morfologia com depressões pequenas e boleadas do sedimento argiloso escuro com artefatos, subjacente aos sedimentos claros estéreis. 


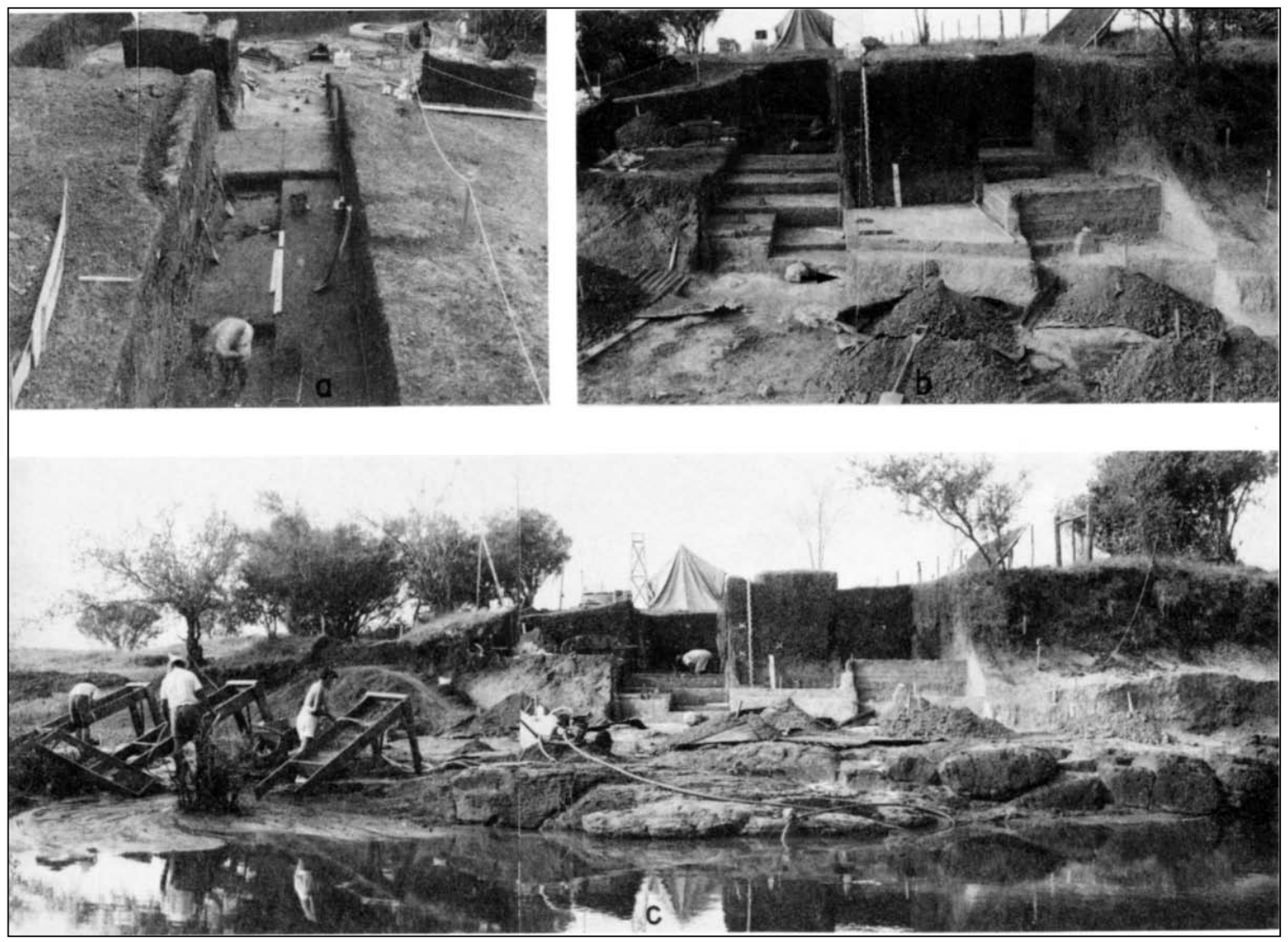

Figura 6. Metodologia das escavações no sítio RS-I-66: a) Vista transversal, da escavação para o Arroio Touro Passo; b-c) Vistas olhando do Arroio. Percebe-se claramente o contato entre as unidades I e II ou horizontes IV e V, holocênicos, ao redor de 6500 anos AP.

O horizonte VII da unidade III inmediatamente sobre a rocha com uma data de 10810 anos AP.

do Vale do rio Guaporé, contamos em 1977 com a acessória do geólogo norte-americano John P. Albanese, Pesquisador Associado ao Smithsonian Institution.

\section{Complexos arqueológicos}

Rio Grande do Sul. Nesse Estado são conhecidas as fases Ibicuí e Uruguay.

\section{Fase Ibicuí}

Sítios. Está representada por três sítios a céu aberto. Dois estão localizados no dique marginal e planície de inundação da margem esquerda do rio Ibicuí (RS-I-50, RS-I-107). O terceiro situa-se junto à margem direita do rio Quaraí (RS-Q-2). Devido à erosão fluvial, eles estão sendo progressivamente destuidos.

As evidências compostas por líticos e restos ósseos de megafauna (Glossoterium robutus e outros) apre- sentam-se reunidos em aglomerados descontínuos ao longo dos rios, numa extensão de até $160 \mathrm{~m}$. No caso de RS-I-50, as evidencieis transpareciam também na margem direita do córrego homónimo, por 300 $\mathrm{m}$ desde a confluência com o rio Ibicuí. O material ocorre em apenas um nível cuja espessura é a dos próprios testemunhos culturais e fósseis, na unidade estratigráfica III, na base do horizonte VIII ou tôpo do horizonte IX. Estão encobertos por sedimentos aluvionais de até $5.5 \mathrm{~m}$ de espessura; na porção superior dos sedimentos ocorrem evidências bem mais recentes de culturas précei arnicas e cerâmicas com pontas de projétil lítico lascadas.

Em área próxima (Sanga Itu), na porção inferior do horizonte IX, restos de troncos carbonizados (por redução natural) forneceram datação de $19350 \pm 240$ anos AP (SI-2352); no rio Quaraí, no Jarau restos de uma lente de carvão foram datados em 29800 \pm 1200 anos AP (SI-2353); porém, em nenhum destes dois casos há evidências de associação com testemunhos culturais. 


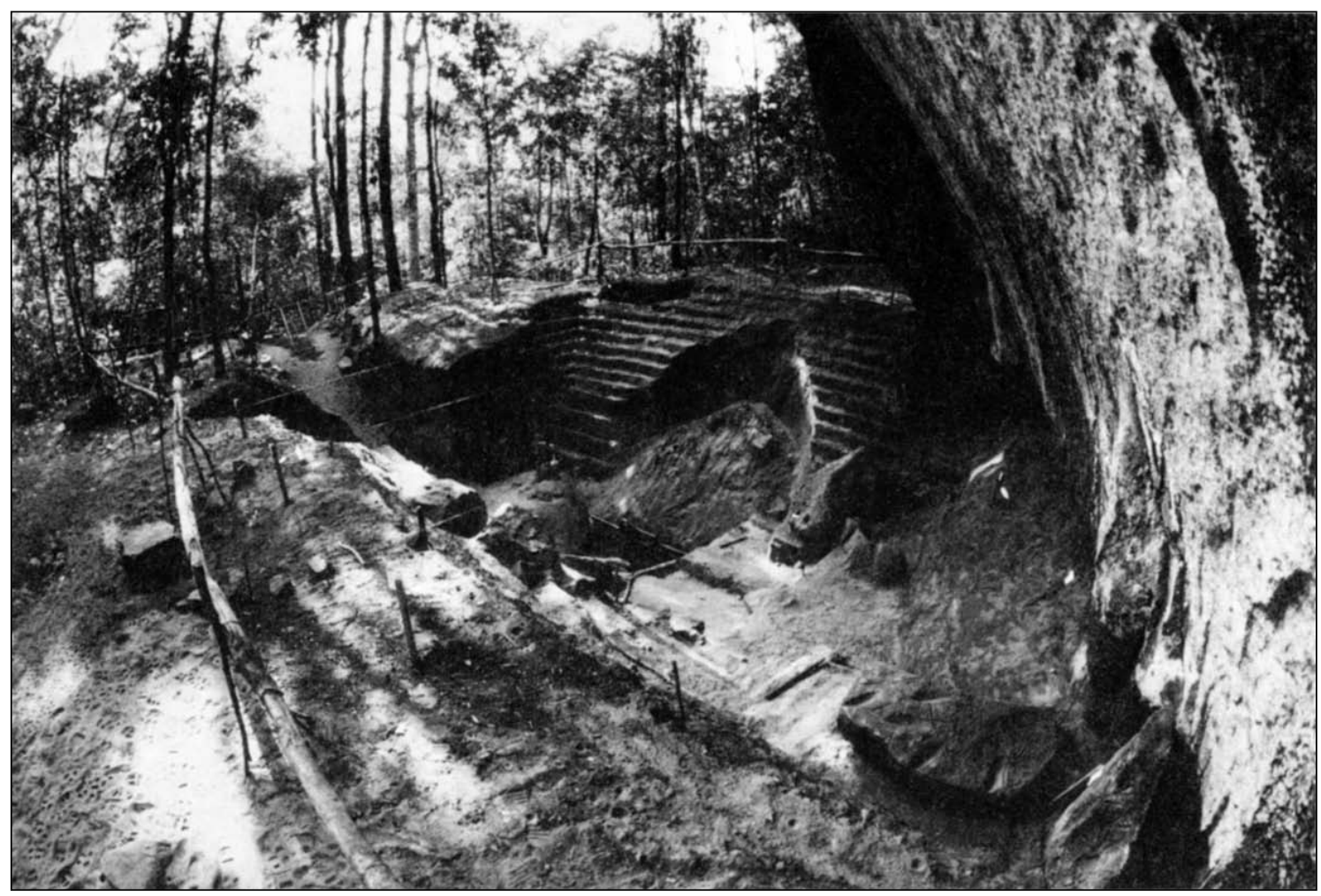

Figura 7. Abrigo-sob-rocha MT-GU-I em processo de escavação.

Artefatos. Foram elaborados por percussão e pressão a partir de núcleos basálticos e placas naturais de arenito metamórfico e raramente em quartzito ou calcedônia (Figuras 2a-f, 9). As três coleções existentes somam 46 evidências líticas e dois fragmentos de osso fóssil contendo ranhuras paralelas, finas e rasas, além dos demais testemunhos fósseis, animais e vegetais. O rol é composto por lascas secundárias com retoques a pressão com algumas prováveis evidências de uso (micro lascados desordenados nas serrilhas), núcleos com evidências de lascamento e percussão, lascas sem evidência de uso, talhadores tipo chopper, raspadores alguns em ponta e de feitura tosca e aglomerados de seixos sem nenhuma evidência cultural (Miller 1969).

Faltam escavações de vulto para com base em algumas centenas de artefatos, poder-se determinar definitivamente a filiação da Fase Ibicuí à tradição paleoindígena com ou sem pontas de projétil.

Fase Uruguay

Sítios. O espaço geográfico abrange desde o baixo rio Quaraí, ao sul, até o baixo rio Ijuí, ao norte, e o rio Uruguay entre estes extremos latitudinais, por ambas as margens. Apesar de presente nas repúblicas do Uruguay (rio Quaraí) e Argentina (rio Uruguay), faltam pesquisas de campo para determinar as reais dimensões espaciais desta cultura.

São conhecidos 21 sítios, dos quais 14 estão junto do rio Uruguay (ver Figura 1). Todos estão sofrendo os efeitos da erosão fluvial anual sub-vertical contra os diques marginais. Via de regra, os sítios situam-se confronte aos baixios e corredeiras. Estratigraficamente ocupam a unidade III e nesta, os horizontes VII e VIII, com espessura sedimentar de 40 até 130 $\mathrm{cm}$. São raras as evidências líticas desde o embasamento rochoso, junto a aglomerados de seixos em "pouding", no horizonte IX ou ou sobre o horizonte $\mathrm{X}$ (leito rochoso do rio Uruguay-basalto ou arenito metamórfico). Estas últimas ocorrências cronologicamente seriam contemporâneas à Fase Ibicuí, sem pontas de projétil, e não há ainda como afirmar ou negar suas associações à Fase Uruguay.

Até 1974 pensava-se que a Fase Uruguay pertencesse a uma tradição paleoindígena sem pontas de projétil, porém, a partir de 1975 a presença das pontas de projétil se tornou patente em seu rol cultural, naqueles sítios que forma alvo de escavações maiores, não 


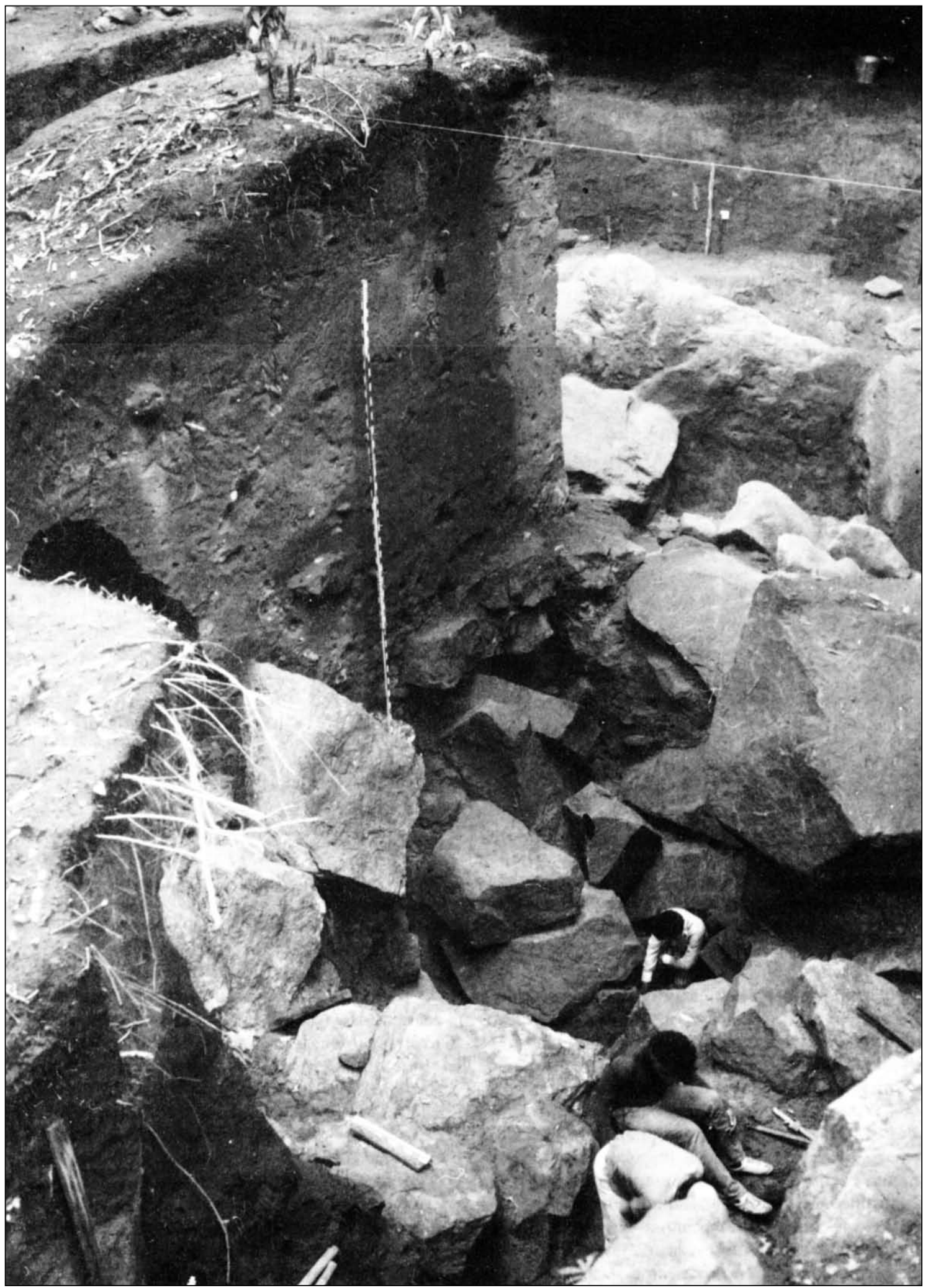

Figura 8. MT-GU-I, mostrando as rochas caidas cubrindo as camadas inferiores. 


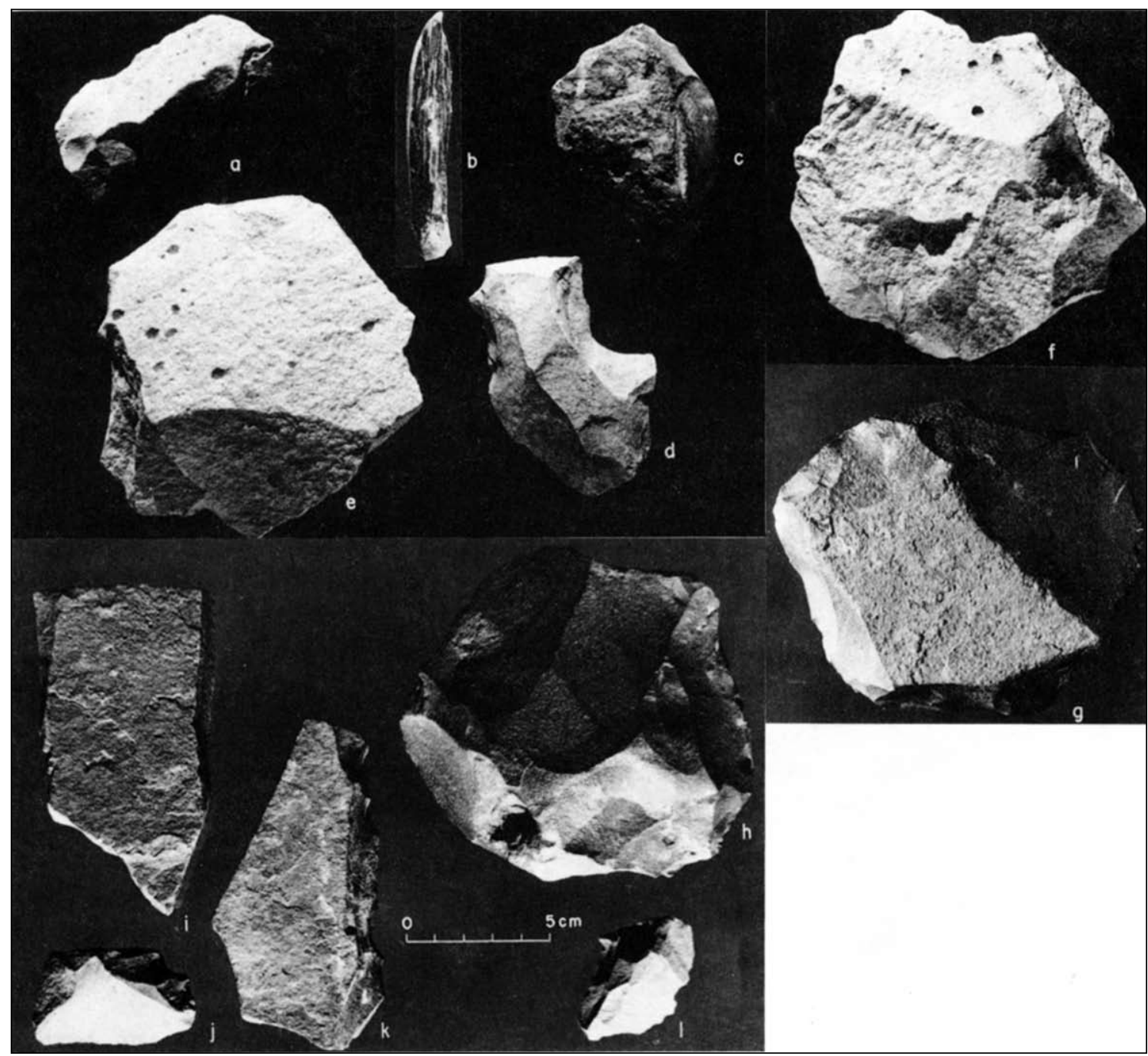

Figura 9. Artefatos da Fase Ibicuí do sítio RS-I-50: a, c-d, j, l) Lascas com e sem retoques; b) Fragmento de osso de fauna pleistocênica com evidências de esfoladura; e-f. g-h) Verso e reverso de núcleos e talhadores; i-k) Núcleos laminares com e sem retoques.

deixando dúvidas quanto a sua filiação à tradição paleoindígena com pontas de projétil lítico lascadas (Figura 10).

Artefatos (Figuras 11, 12, 13, 14 y 15). Por razões alheias a nossa vontade, as análises das evidências interdisciplinares e arqueológicas pouco progrediram e ainda encon-tram-se a nível preliminar.

Os utensílios mais diagnósticos englobam principalmente as pontas de projétil lítico lascadas e pedunculadas, de formas variadas, de tamanho médio a pequeno $(4.9 \mathrm{a} 2.9 \mathrm{~cm})$, estreitas e raramente largas $(1.6$ a $3.4 \mathrm{~cm})$, bifaciais, com retoque à pressão e principalmente em calcedônea; facas bifaciais com retoque à pressão, de médias a pequenas (12.4 a 4.2 $\mathrm{cm}$ ), raspadores circulares, laterais e terminais pequenos $(2.7$ a $3.9 \mathrm{~cm})$; pré-formas lanceoladas bifaciais sem retoque à pressão. Além destes há abundância de micro-lascas resultantes de lascamento e retoque à pressão e percussão; lascas e lâminas pequenas a medianas $(1 \mathrm{a} 4.2 \mathrm{~cm})$ com e sem retoque intencional e/ou com evidência de uso (micro lascamentos ordenados e contínuos até $1.5 \mathrm{~cm}$ - ou desordenados nas serrilhas); núcleos de 3 a $19 \mathrm{~cm}$, percutores de 5.2 a $7.9 \mathrm{~cm}$ esferoides a cilíndricos; pedras bigorna e talhadores tipo chopper, em pequena quantidade, elaborados em seixos rolados, com gume reto a convexo, lateral ou terminal, e núcleos esgotados originando raspadores pequenos circulares e altos. 


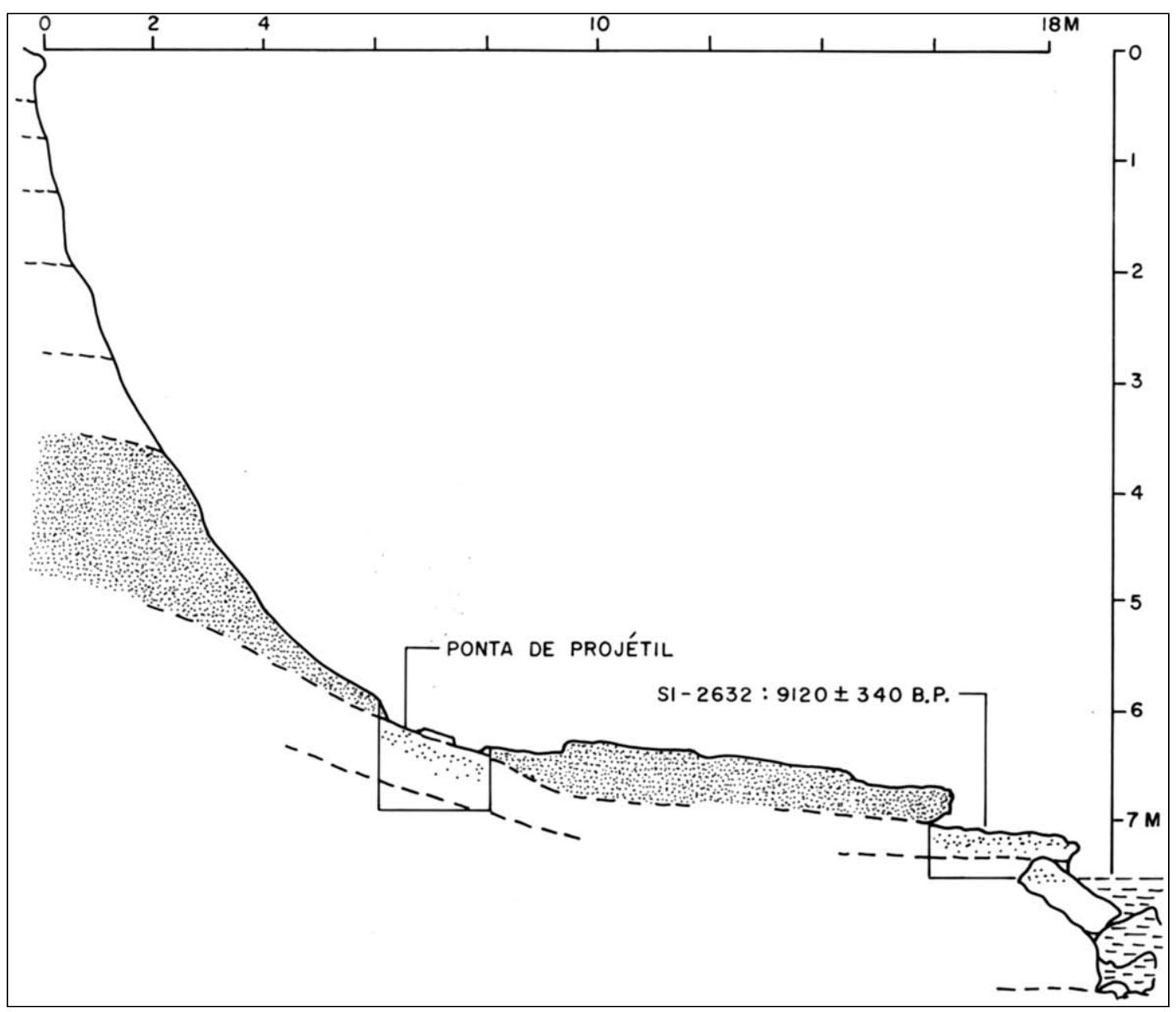

Figura 10. Sítio RS-I-70, onde foi encontrada uma ponta de projétil abaixo da unidade II com datação de $\mathrm{C}^{14}$.

Ao todo foram reunidas, in situ, cerca de 3.240 evidências líticas: 11 pontas de projétil, 38 raspadores, 18 percutores, 29 núcleos esgotados, 37 pedras bigorna, 167 lascas grossas e grandes, 247 lascas médias, 102 lâminas médias, 247 lascas pequenas e mais de dois milhares de micro-lascas. Em sua maioria as lascas são prismáticas e obtidas por percussão em plataformas naturais e/ou preparadas de modo simples. As lascas finas foram obtidas por percussão indireta ou pressão. Outras foram obtidas a partir de placas tabulares partidas de maneira a formarem lâminas de lados quase paralelos e retocados terminalmente, como bisel ou raspador. Tanto na Fase Uruguay como na Ibicuí, as proporções dos utensílios líticos são determinantes tecnológico-culturais, uma vez que a matéria prima sã permite dimensões bem acima das adotadas (como ocorre no complexo précerâmico Itaquí; Miller 1969). 86\% tem o basalto como matéria-prima, $10 \%$ em arenito metamórfico e $4 \%$ em calcedônia, quartzito, quartzo, ágata, etc. Também a matéria-prima utilizada é uma adoção cultural-tecnológica, visto a abundância de todas.

Padrão de assentamento. Escavações em RS-I-69 forneceram um quadro bastante claro do padrão de assentamento. Além da localização num ângulo entre um córrego e o rio, confronte a uma corredeira, tem às costas rma bacia de drenagem com mata ciliar (conforme fósseis vegetais), ladeada por elevações suaves (coxilhas) e pedregosas. O solo de assentamento (fóssil ou paleo) era ora arenoso ora limo-argiloso e esporadicamente inundável por águas calmas, conforme morfologia de paleosuperfícies e moldes negativos impressos naturalmente na porção inferior da unidade II horizonte VI. No solo de assentamento, os restos líticos (de frutos e ósseos quando presentes) 


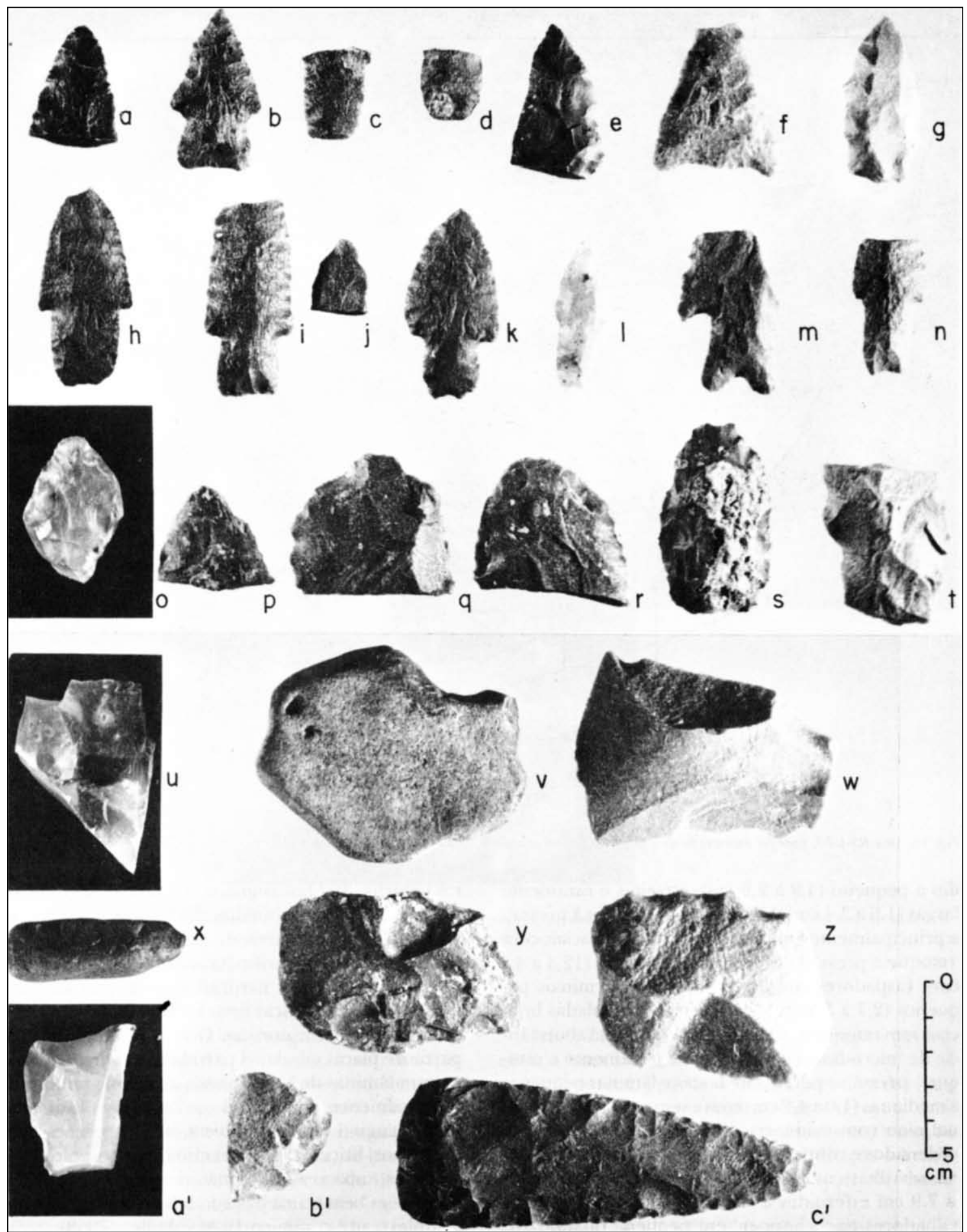

Figura 11. Artefatos líticos do sítio RS-I-66: a-f, h-n) pontas de projétil: a-c, do horizonte VII paleoindígena (remanescente); d-f, h-n) dos horizontes III a VI arcaico; g, o-t y b') pré-formas bifaciais: g, o-q, dos horizontes III a VI; r-t, y, b') do horizonte VII. $\left.\mathbf{u}, \mathbf{w}, \mathbf{a}^{\prime}\right)$ lascas com evidências de uso e retoque; $\mathbf{v}, \mathbf{x}$ ) seixos com evidências de percussâo; $\mathbf{z}$ ) raspador (?); c') biface, todos do horizonte VII, Fase Uruguay. 


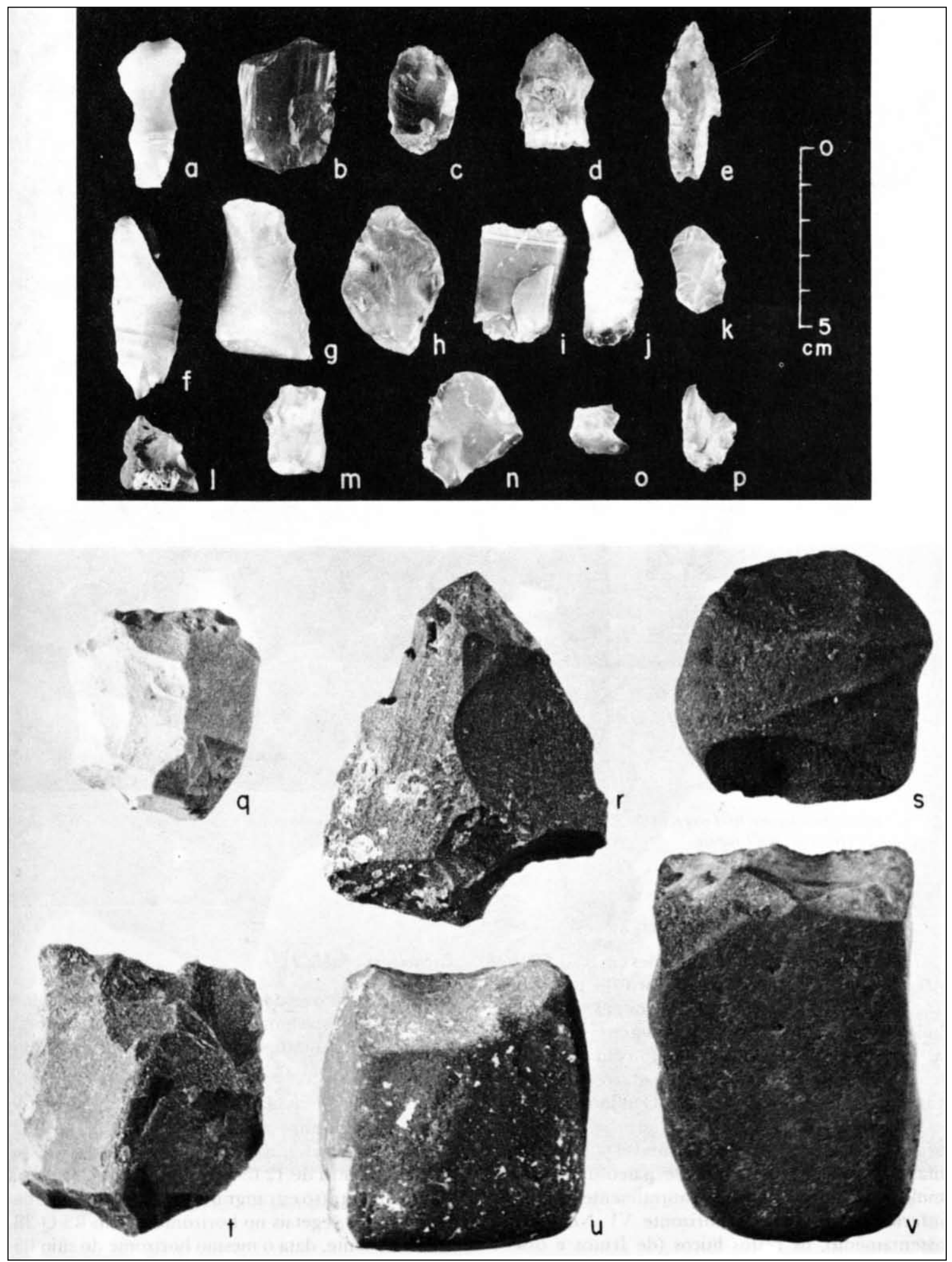

Figura 12. Artefatos líticos do sítio RS-I-66: a-p) lascas diversas com e sem evidências de uso e artefatos em calcedônia; b, g-h) raspadores; d) ponta de projétil do horizonte VII; e) ponta de projétil do horizonte III; q-r, t-v) raspadores; s) percutor, todos do horizonte VII, Fase Uruguay. 


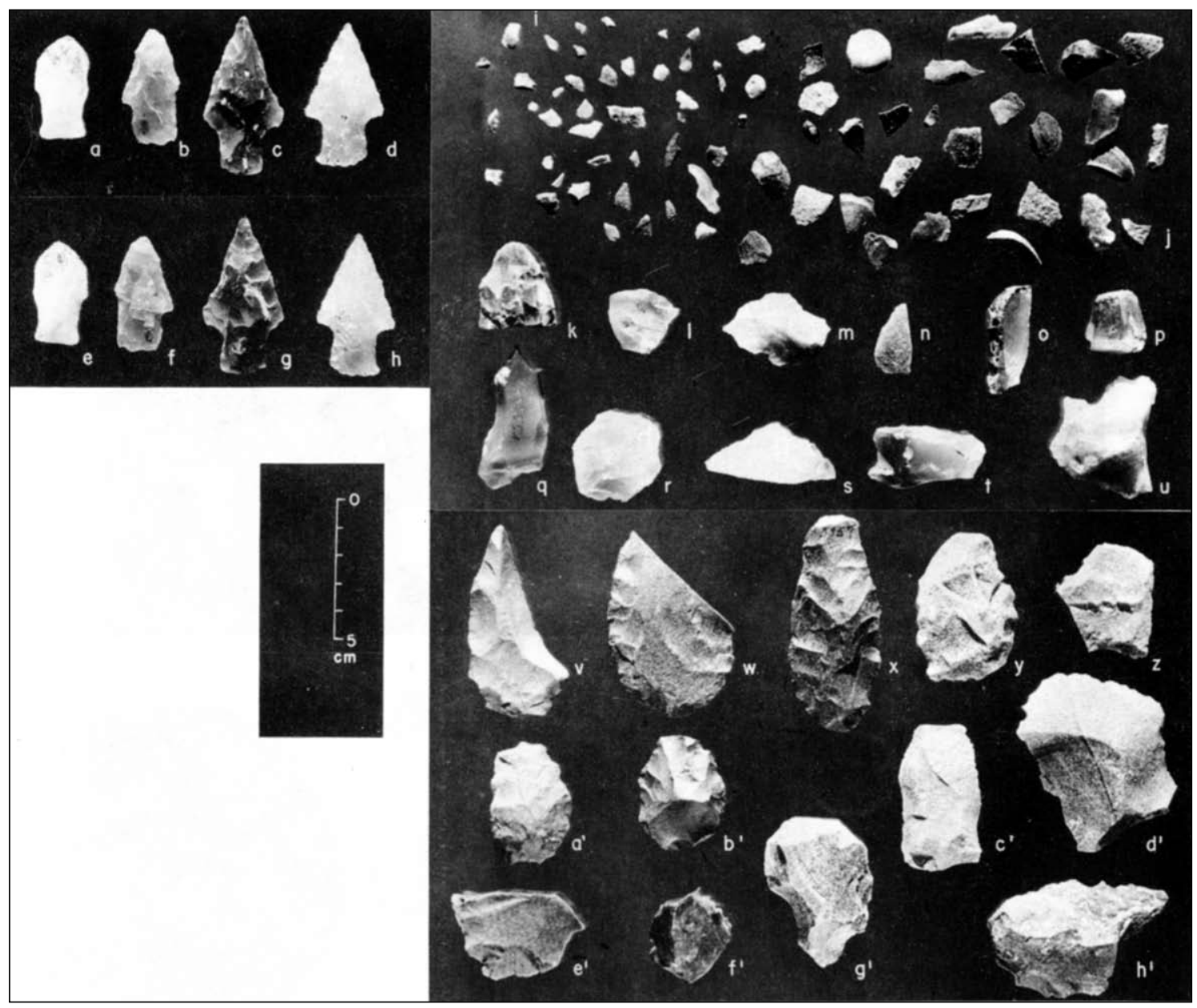

Figura 13. Artefatos líticos dos sítios RS-I-69 e RS-I-70 (d, h): a-h) verso e reverso de pontas de projétil; i-j) micro-lascas; $\mathbf{k}, \mathbf{v}, \mathbf{y}, \mathbf{a}$ '-b', g') pré-formas bifaciais, todos dos horizontes VII e VIII, Fase Uruguay.

forman conjuntos ao redor de concentrados de carvão (testemunho de fogueira e fogão quando delimitado por círculo de seixos e matacões).

\section{Cronologia (Tabla 1)}

Existem 19 datações pelo $\mathrm{C}^{14}$ diretamente associadas e relacionadas (estratigráfica e culturalmente) ao paleoindígena e uma indiretamente (somente estratigrafia).

Quanto as duas datações mais antigas, uma de $12770 \pm 220$ anos AP (SI-801) está diretamente (cultural e estratigráficamente) relacionada à Fase

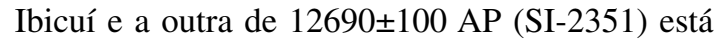
indiretamente (só estratigráficamente) associado, datando restos vegetais no horizonte IX em RS-Q-2B. Indiretamente, data o mesmo horizonte do sítio RS-Q-2. Em RS-Q-2 não apareceram pontas de projétil nas escavações. Os líticos se assemelham mais aos das Fase Ibicuí, razão pela qual este sítio a essa dataçáo indireta são hipotéticamente atribuídos è Fase Ibicuí.

As dezoito dataçôes entre $11555 \pm 230$ anos AP (SI-3750) e $8585 \pm 115$ anos AP (SI-2636) pertencem à Fase Uruguay. Todas estão perfeitamente relacionadas cultural e estratigráficamente (Figura 16). Cinco datam específicamente á pontas de projétil pedunculadas, sendo a mais antiga de $11555 \pm 230$ anos AP (SI-3750) e a mais recente de $9120 \pm 340$ anos AP (SI-2632). Os sítios são: RS-1J-57, RS-IJ68, RS-I-69, RS-I-70, e RS-I-72.

Ao menos no rio Uruguay onde todas as amostras de carvão para o $\mathrm{C}^{14}$ provêm de sob o Estrato-guia, 


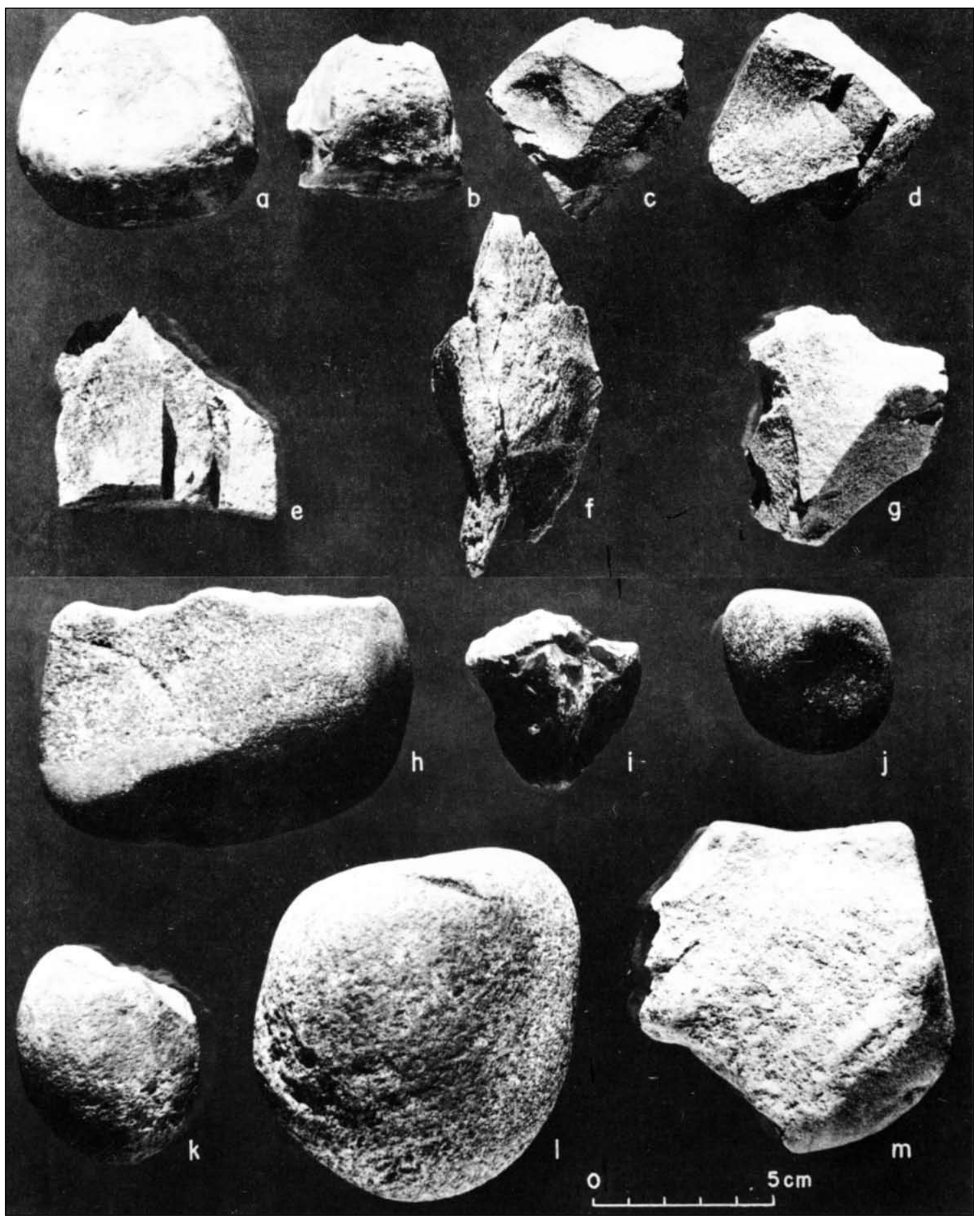

Figura 14. Artefatos líticos do sítio RS-I-69, profundidade 6.8 m; a, h-m) percutores e bigornas; b, c, g) núcleos; d-f) lascas re-agrupadas em núcleos. 


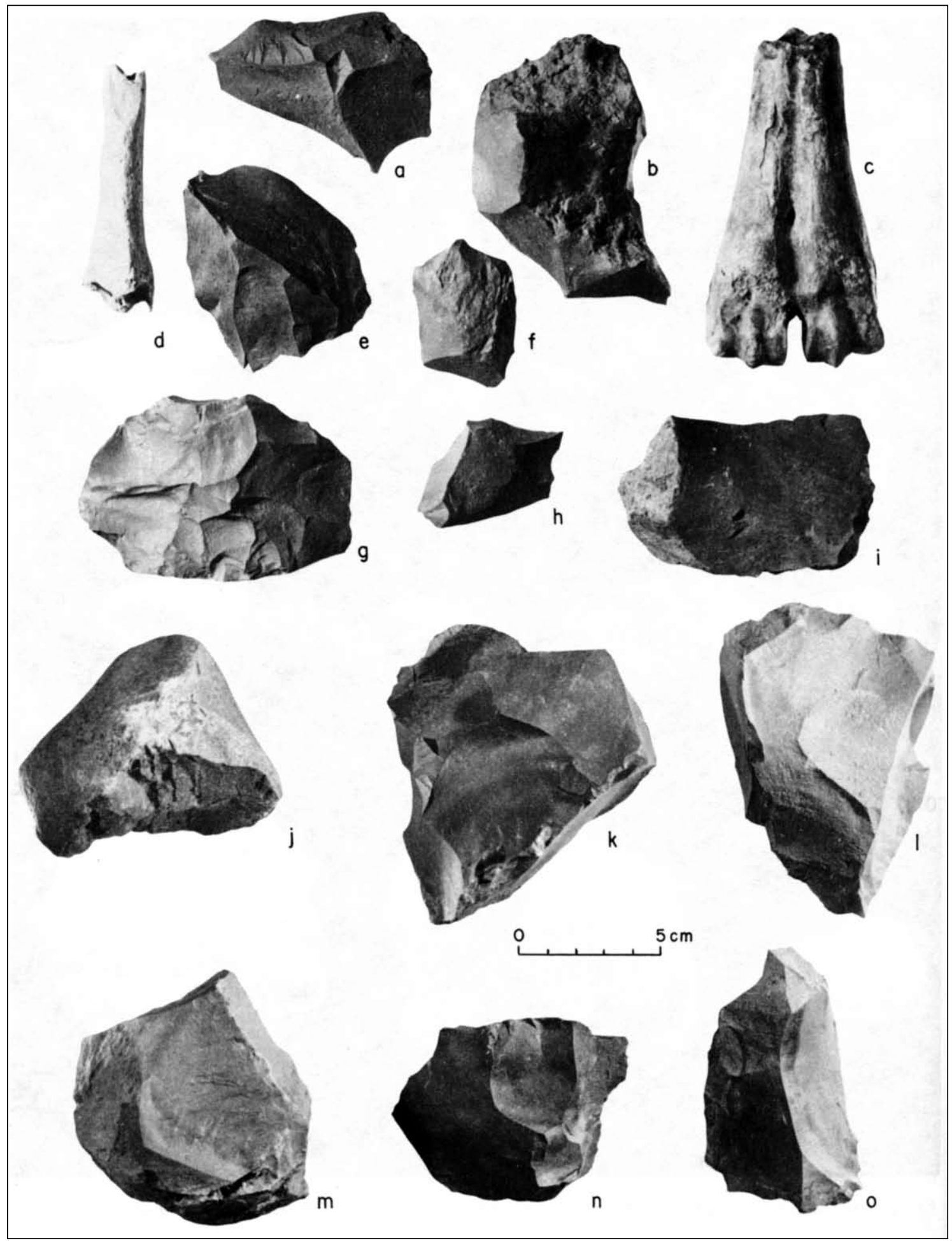

Figura 15. Artefatos do sítio RS-I-70: a, e-i, o) lascas grandes com poucos retoques e raras evidências de uso; b, k-n) lascas espessas ou núcleos; j) percutor; c-d) ossos com evidências de modificaçôes pelo ser humano. 
há uma dessintonia entre a datação desse Estratotipo e as dataçôes inferiores a ela. Ou o Estrato-guia está incorreto ou as datações para menos estão contaminadas para menos.

Seis dataçôes provém de amostras do horizonte IX, que no rio Quaraí e rio Ibicuí é bem mais espesso que no rio Uruguay e pelo visto, bem mais antigas que as aqui apresentadas. Assim, se houver evidências culturais paleoindígena, será nos sedimentos do horizonte IX dos rios Quaraí e Ibicuí que eles deverão ser pesquisados. Até agoras, encontramos somente fósseis animais, sem associação cultural.

Mato Grosso e Rondônia. Nesses Estados é conhecido o Complexo Dourado e, para Rondônia, o Complexo Periquitos.

\section{Complexo Dourado}

Sítios. Está representada por dois sítios: MT-GU-1 E RO-RO-7 (Figura 17). Essas duas ocorrências atribuem uma extensão geográfica mínima de 300 km contínuos (Miller 1983: 12), dentro do Refúgio Guaporé ao longo da porção superior da encosta ocidental da Chapada dos Parecis, paralelo ao médio rio Guaporé.

Durante a ocupação paleoindígena da região, nos abrigos-sob-rocha houveram vários desabamentos de blocos. Seria esta a causa de ocupação apenas como acampamento e não habitação?

Esses dois sítios apresentam, na Unidade Superior sedimentar, evidencias de fases cerâmicas e pré-

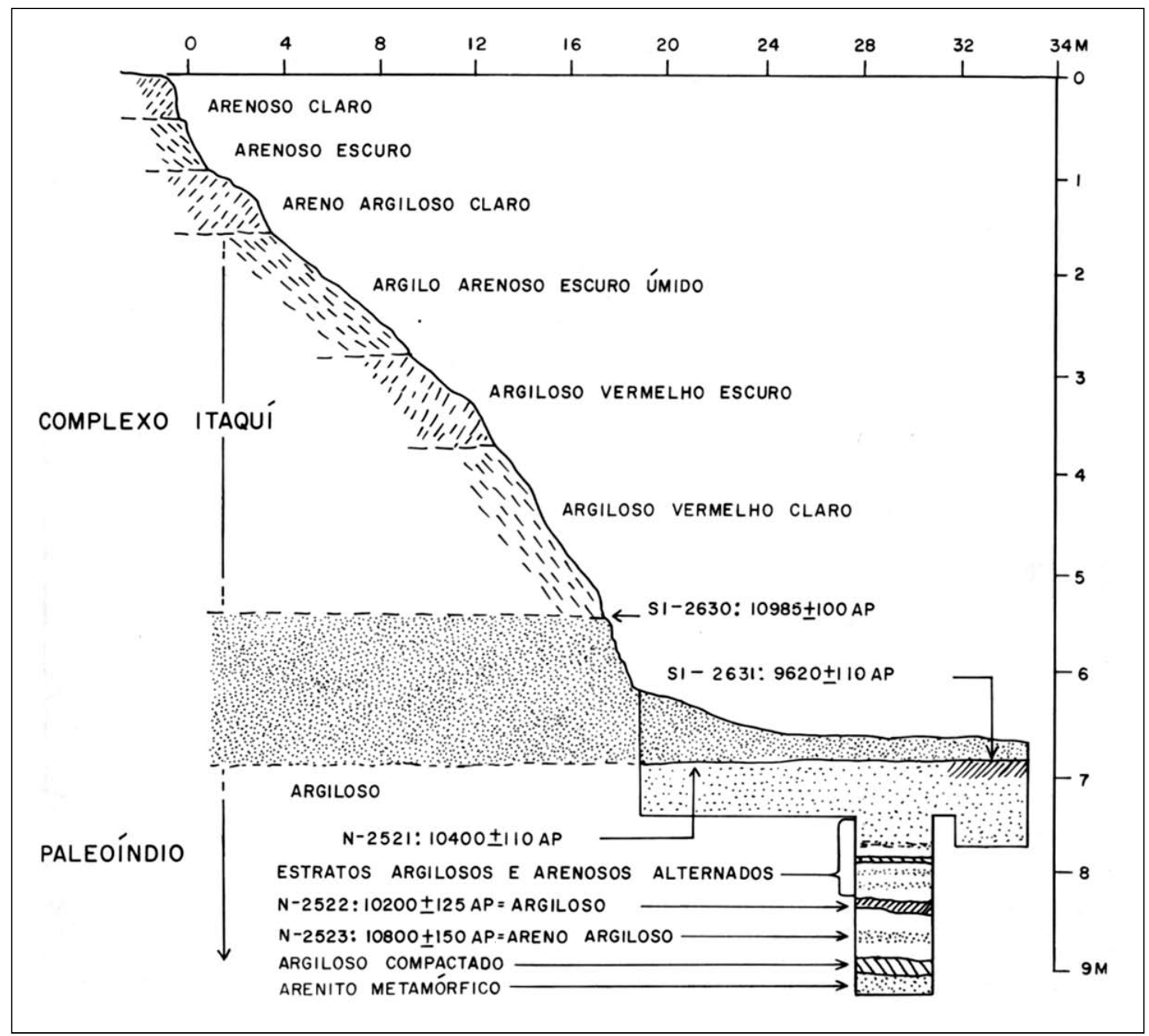

Figura 16. Estratigrafia do sítio RS-I-69 e procedência das dataçôes. 


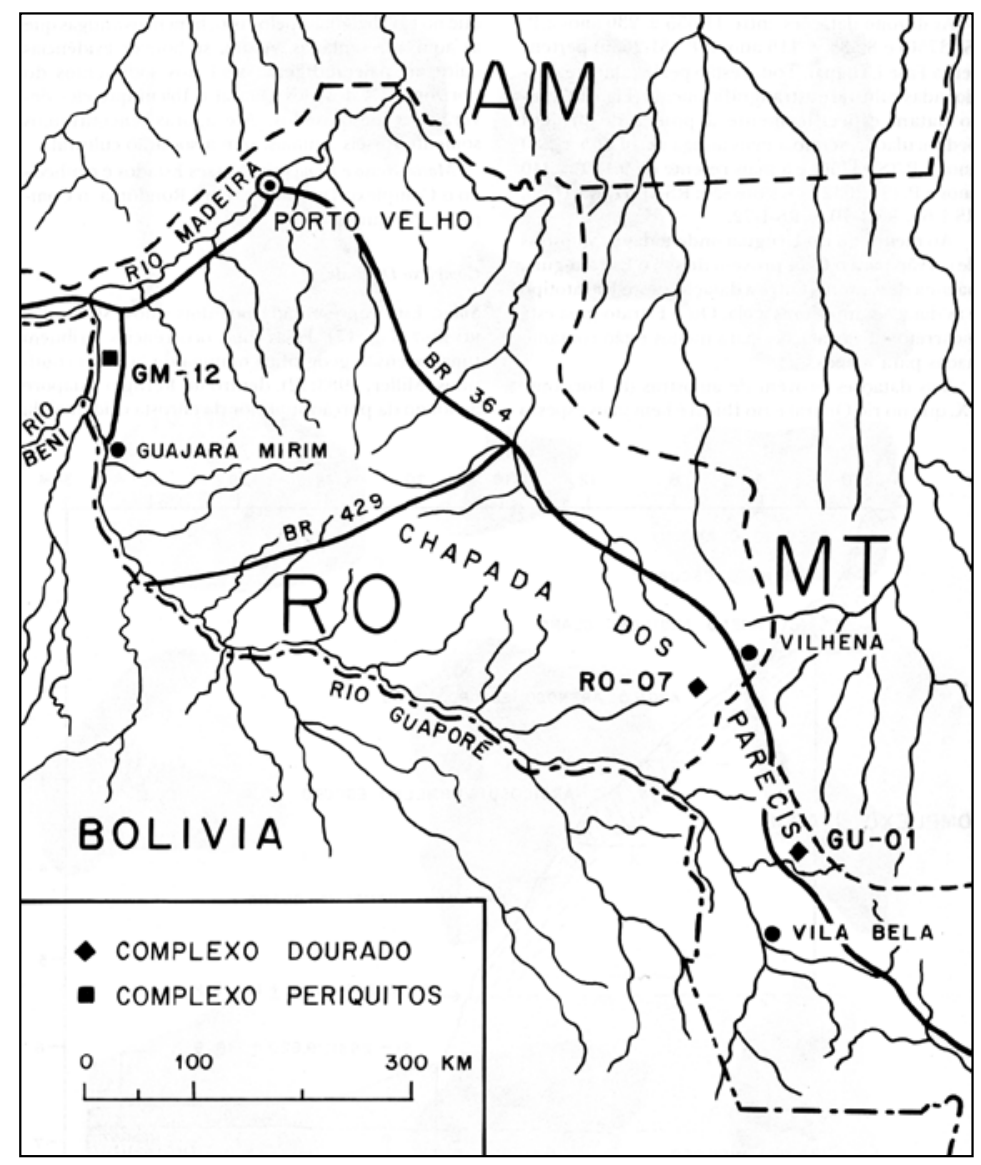

Figura 17. Localização dos sítios pesquisadas em Mato Grosso e Rondônia.

cerâmica arcaica, com raros enterramentos e arte rupestre gravada.

Em ambos os sítios, as unidades e horizontes apresentam as mesmas feições, com dimensões verticais e horizontais distintas, menores em RO-RO-7. Os testemunhos culturais compostos por líticos, porções de resina, raros caroços de palmeira carbonizados e carvão, dispôemse em focos não muito definidos. Contudo, o carvão e cinzas, em finas camadas as vezes em lentes, permitem o controle das superfícies culturais desenvolvidas em solo arenoso a arenoso-humoso.

Artefatos (Figura 18). Matéria prima lírica existe nas paredes areníticas dos próprios abrigos e blocos angulares provenientes dos tetos dos mesmos. $\mathrm{O}$ arenito metamórfico e basalto provém de desabamentos, do capeamento da escarpa, em frente aos abrigos. $\mathrm{O}$ granito, quartzito e quartzo em forma de seixos ocorrem nos leitos dos pequenos riachos em frente e abaixo dos abrigos. A matéria prima mais usada foi o basalto (púrpura a avermelhado) e o quartzito (várias cores). O quartzo (leitoso), a calcedônia (creme), granito, biotito e arenito silicificado também foram usados. Esses materiais ocorrem em todos os níveis da ocupação paleoindígena.

As evidências culturais mais comuns são as lascas resultantes por percussão em basalto. Seis dessas lascas de forma originalmente sub-circular de 4.2 a $6.3 \mathrm{~cm}$ de eixo maior, apresentam um lado desgastado por fricção resultante do desgaste na execução de petróglifos. Os artefatos são poucos e compreendem, além de lascas com abrasão ou retoques por pressão (até $4.2 \times 3.5 \times 0.4 \mathrm{~cm}$ ): uma lâmina de biface lascado por percussão apresentando entalhes laterais (encabamento?) em rocha muito alterada, com $14 \times 11 \times 2 \mathrm{~cm}$; raspadores altos em basalto e quartzito e arenito metamórfico, com retoques laterais, entre $4 \times 2 \times 3 \mathrm{~cm}$ e $8.5 \times 6.3 \times 5.1 \mathrm{~cm}$; raspadores baixos de secção triangular entre $7 \times 2 \times 0.5 \mathrm{~cm}$ e $5.6 \times 2.1 \times 0.6$ 


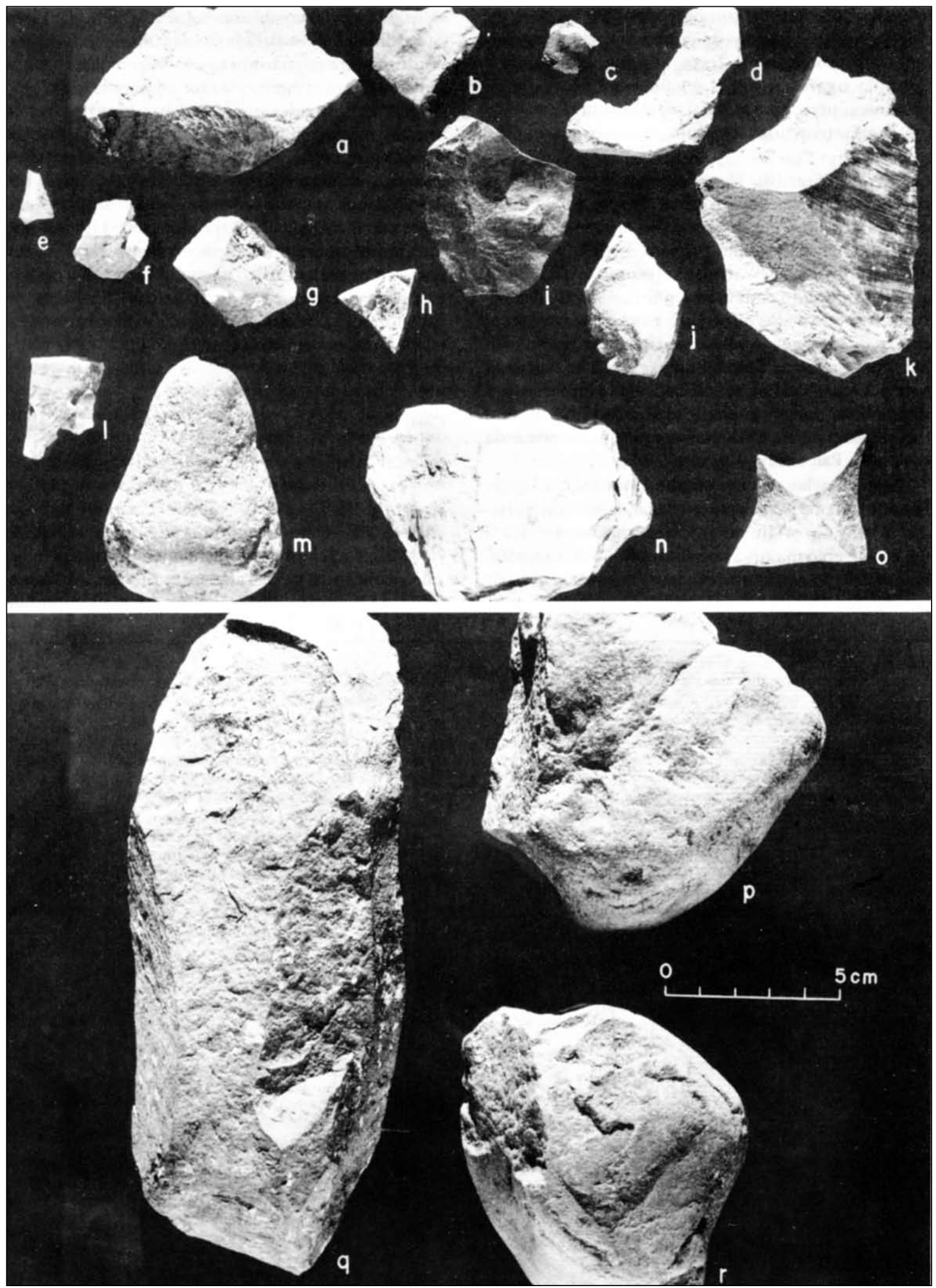

Figura 18. Artefatos líticos do sítio MT-GU-1 em profundidade de 520-540 m: a-1, o) lascas finas, espesas e poliédricas com e sem evidências de uso e retoque; $\mathbf{m}, \mathbf{p}, \mathbf{q}$ ) núcleos; $\mathbf{n}, \mathbf{r}$ ) percutores e talhadores (?) 
$\mathrm{cm}$; percutores em seixos com una extremidade ativa, entre $5 \times 4.6 \times 5.4 \mathrm{~cm}$ e $11 \times 7.4 \times 6 \mathrm{~cm}$ em quartzito, quartzo, granito e raramente em arenito metamórfico e basalto. Além das evidências líticas ocorrem restos de caroços de palmeiras carbonizados e nódulos de resina sem claras evidências de uso ou prática cultural.

\section{Complexo Periquitos}

Sítios. A atividade de garimpo e mineração de ouro tem extraído inúmeros restos fósseis de megafauna extinta e flora, ao longo de cerca de $400 \mathrm{~km}$ com corredeiras, cachoeiras e saltos que constituem o alto rio Madeira, sendo que essa atividade extrativa mineral se concentra nesses acidentes fluviais. Até o presente, a Cachoeira dos Periquitos é o mais importante, visto que o horizonte fossilífero também tem apresentado fósseis humanos, dos quais infelizmente só restou uma mandíbula com um molar e um prémolar juntos (o maquinário de mineração destruiu os ramos verticais e mais seis dentes). Originalmente a dentição era completa, restando as raízes dos 16 dentes. Três outras mandíbulas e dois crâneos, todos fósseis e quase intactos, que pudemos examinar ligeiramente, tiveram destino ignorado. Há notícias de outras ocorrências de fósseis humanos nesta e noutras cachoeiras do rio Madeira. Também foram resgatados restos ósseos não fossilizados, artefatos cerâmicos, líticos polidos, etc., sem relação alguma com o Complexo Periquitos.

Artefatos. O maquinário -dragas e outros- penetram nos horizontes sedimentares argilosos e arenosos até o leito granítico do rio sugando tudo a seu alcance: sedimentos, concreções, seixos, etc., restos da biota -fósseis ou náo- mutilando ou simplesmente destruindo e transformando em pó, nas moendas. Em uma das oportunidades que nos foram dadas de acompanhar esse trabalho de mineração, obteve-se das peneiras de balsa um biface lítico lanceolado com $7.2 \times 2.6 \times 1.2 \mathrm{~cm}$ em matéria prima extremamente alterada, mas sem dúvida resultante de um lascamento por percussão. Nessa oportunidade ainda resultaram algumas lascas e pequenos seixos em quartzito, sem retoque. Essas evidências quer de atividade cultural ou não, fosseis da paleobiota e do homen, sempre apresentam-se encobertas parcial ou totalmente

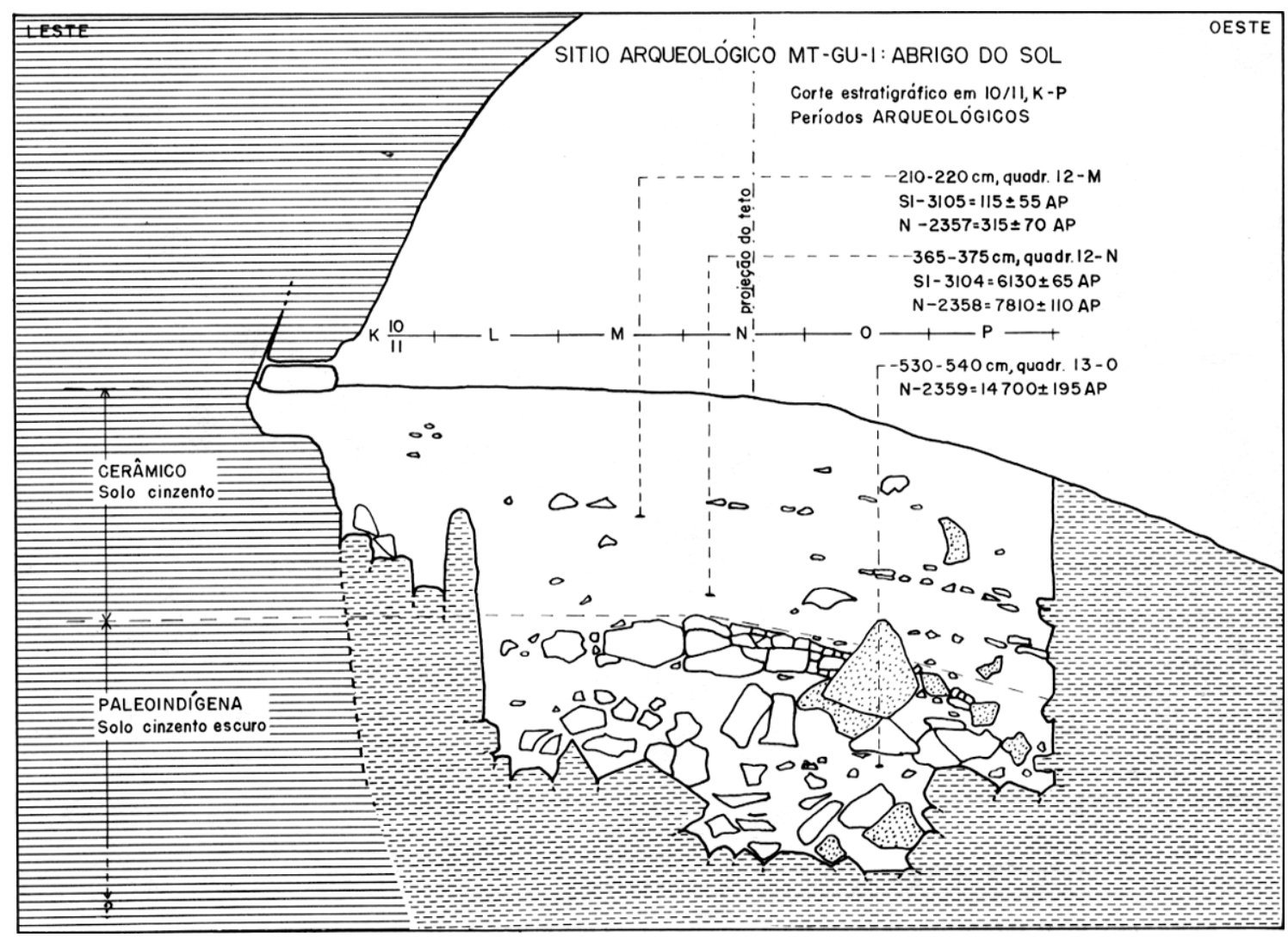

Figura 19. Perfil estratigráfico do sítio MT-GU-1 com a procedência de algunas datações. 
por concreções laterítico-argilosa ou argilo-arenosa densamente cimentadas, com pedregulho pequeno (raramente até $4.5 \times 2.2 \times 1.8 \mathrm{~cm}$ ).

\section{Cronologia}

Tanto o Complexo Dourado como o Complexo Periquitos são muito mal conhecidos pelas condições em que até agora foram pesquisados. Para o Complexo Dourado temos datações do abrigo
MT-GU-1, entre 8930 \pm 100 anos AP (SI-3736) e $10600 \pm 130$ anos AP (N-3223) para seu final e mais de 14700 \pm 195 anos AP para seu começo, se esta data foi aceitável (Figura 19).

Para o Complexo Periquitos não há datações. Apenas é possível uma estimativa crono-sedimentar onde suas evidências materiais se encontram em transição pleisto/holocênica, ou seja ao redor de 12000-13000 anos AP.

\section{REFERENCIAS CITADAS}

AB'SÁBER, A. N., 1977. Espaços ocupados pela expansão dos climas secos na América do Sul, por ocasião dos períodos glaciais quaternários. Paleoclimas 3: 1-19.

BIGARELLA, J. J., 1971. Variações climáticas no quaternário superior do Brasil e sua datação radiométrica pelo método do Carbono 14. Paleoclimas 1: 1-22.

BOMBIM, M., 1976. Modelo paleoecológico evolutivo para o neoquaternário da região da campanha-oeste do Rio Grande do Sul (Brasil). A formação Touro Passo, seu conteúdo fossilífero e a pedogênese pós-deposicional. Comun. Mus. PUCRGS 15: 1-90.

BRASIL, DNPM. 1979. Proyecto RADAMBRASIL. Folha SD, 20 Guaporé. Rio de Janeiro (Levantamento de Recursos Naturais) 19.

BROWN JR., S. KEITH y A. AB'SÁBER, 1979. Ice-age forest refuges and evolution in the neotropics: Correlation of paleoclimatological, geomorphological and pedological data with modern biological endemism. Paleoclimas 5: 1-30.

CORREA, M., 1980. International Research Program. Research on geology and paleoclimatology of Pleistocene and Holocene periods. En Report on Chilean Univ. Life 7 (summer): 10-11. Embassy of Chile, Cult. Dep., 1732 Mass. Ave., N.W., Washington. D.C. 20036.

FORTES, A., 1964. Compêndio de Geografia Geral do Rio Grande do Sul. Porto Alegre. Sulina.

MILLER, E., 1969. Pesquisas arqueológicas efetuadas no oeste do Rio Grande do Sul (Campanha-Missões). Programa Nacional de Pesquisas Arqueológicas. Resultados preliminares do terceiro ano. 1967-8. Publ. Avulsas Mus. Pa. Emílio Goeldi 13: 13-30.

— 1976. Resultados preliminares das pesquisas paleoindígenas no Rio Grande do Sul. Actas del Congreso Internacional de Americanistas vol. 3: 483-491.
— 1978 Ms-a. Novos subsidies às pesquisas paleoíndigenas no Rio Grande do Sul e Mato Grosso. V Congreso Nacional de Arqueologia Argentina. San Juan, abril de 1978.

1978 Ms-b. Arte rupestre no noroeste de Mato Grosso. Primeras Jornadas de Arte Rupestre de la provincia de San Luis, Argentina. San Luis, abril de 1978.

- 1978 Ms-c. O Paleoindio no Rio Grande do Sul e Mato Grosso. Seminário Internacional de tecnologia paleoindia. Antofogasta, octubre de 1978.

- 1978 Ms-d. Relacionamento entre as cronologias arqueológicas e estratigráficas no Rio Grande do Sul. Brasil. VI Congreso Nacional de Arqueologia del Uruguay y Salto, noviembre de 1978.

— 1983. História da cultura indígena do alto Médio-Guaporé (Rondônia e Mato Grosso). Dissertação de Mestrado em História da Cultura Brasileira, PUCRS, Porto Alegre.

— 1985 Ms Faixa cronológica do sudoeste Amazônico e culturas nela inscritas até o presente. III Reunião Científica da Sociedade de Arqueologia Brasileira-SAB. Goiás, Goiânia, septiembre de 1985.

- 1986. A ocupação humana pre-histórica do Pantanal do Guaporé-Rondônia. Anais do V Encontro de Pesquisadores da Amazônia, Manaus.

MORENO, J. A., 1961. Clima do Rio Grande do Sul. Porto Alegre, Diret. Terras e Colonização, Secç. Geogr.

SCHMITZ, P., A. S. BARBOSA y M. B. RIBEIRO (Eds.), 1981. Temas de arqueologia brasileira. I Paleoindio. Inst. Goiano Pré-Hist. Antrop. 5: 49. 